\title{
A spatial investigation of the environmental controls over cryoconite aggregation on Longyearbreen glacier, Svalbard
}

\author{
H. J. Langford ${ }^{1,2}$, T. D. L. Irvine-Fynn ${ }^{3}$, A. Edwards ${ }^{4}$, S. A. Banwart ${ }^{2}$, and A. J. Hodson ${ }^{1,5}$ \\ ${ }^{1}$ Department of Geography, University of Sheffield, Winter Street, Sheffield S10 2TN, UK \\ ${ }^{2}$ Kroto Research Institute, University of Sheffield, Broad Lane, Sheffield S3 7HQ, UK \\ ${ }^{3}$ Department of Geography and Earth Science, Aberystwyth University, Aberystwyth SY23 3DB, UK \\ ${ }^{4}$ Institute of Biological, Environmental and Rural Sciences (IBERS), Aberystwyth University, Aberystwyth, SY23 3DB, UK \\ ${ }^{5}$ Arctic Geology, University Courses on Svalbard, P.O. Box 156, 9191 Longyearbyen, Svalbard, Norway
}

Correspondence to: H. J. Langford (h.langford@sheffield.ac.uk)

Received: 9 January 2014 - Published in Biogeosciences Discuss.: 27 February 2014

Revised: 20 August 2014 - Accepted: 9 September 2014 - Published: 7 October 2014

\begin{abstract}
A cryoconite granule is a near-spherical aggregation of biota and abiotic particles found upon glacier surfaces. Recently, microstructural studies have revealed that photosynthetic microorganisms and extracellular polymeric substances (EPS) are omnipresent within cryoconite granules and have suggested their importance as biological "forming factors". To assess these forming factors, and their biological control over aggregate size and stability, across a typical Arctic valley glacier surface, a suite of rapid, spectrophotometric, microplate methods were utilised. Subsequent spatial mapping of these data revealed distinct patterns. Labile carbohydrates were found to increase up-glacier, suggestive of EPS production for cryoprotection and nutrient assimilation. Conversely, pigment concentrations were found to increase towards the glacier terminus and valley sides, suggestive of allochthonous input, a general reduction in physical disturbance and of the build-up of photosynthetic pigments and less labile cyanobacterial sheath material. Aggregate size was found to increase towards the glacier edges, linked to the input of particulate matter from the valley sides, and to broadly increase down-glacier, in the same way as pigment concentrations. Statistical analyses of transect data revealed that the photoautotrophic count and carbohydratechlorophyll ratio of the cryoconite sampled could explain $83 \%$ of the measured variation in aggregate size and stability. Considering solely aggregate size, the number and length of photoautotrophic filaments could explain $92 \%$ of the variation in this parameter. These findings demonstrate the twodimensional distribution of key biological controls upon cry-
\end{abstract}

oconite aggregation for the first time, and highlight the importance of filamentous cyanobacteria and EPS production to the development of stable cryoconite granules.

\section{Introduction}

Cryoconite granules are biologically active aggregations of microorganisms, mineral particles and organic matter. Located on the surface of glaciers and ice sheets, cryoconite material harbours a complex and variable microbial community (Hodson et al., 2008; Edwards et al., 2011; Cameron et al., 2012), sourced largely from aeolian input (Pearce et al., 2009). This material is important as it acts as a biogeochemical reactor (Hodson et al., 2008; Stibal et al., 2012), feeding proglacial environments, and also acts to darken the surface of the glacier (Takeuchi et al., 2001; Yallop et al., 2012), driving ice melt. The biogeochemical characteristics of cryoconite material are variable, both between granules and between cryoconite holes, the quasi-cylindrical holes formed as they preferentially melt into the ice (McIntyre 1984; Fountain et al., 2008). Cryoconite material sits upon and within a dynamic supraglacial weathering crust environment (Müller and Keeler, 1969), within which physical and hydrological influences act upon it, in addition to biogeochemical interactions. Radionuclide analysis (Tieber et al., 2009) and timelapse imagery (Irvine-Fynn et al., 2011) both suggest that, despite seasonal meltwater flow, cryoconite can reside on the ice surface for extended time periods, up to decades, thereby 
creating complex microbial community structures and promoting the development of niche communities and microenvironments (Edwards et al., 2013; Zarsky et al., 2013).

Microstructural evaluation of cryoconite granules from across the Arctic reveals distinct variability in the location and quantity of photosynthetic microorganisms, heterotrophic microorganisms and labile organic matter between glaciers, resulting in differing aggregate size and stability. Langford et al. (2010) proposed a hypothesis for the formation of cryoconite granules, which highlighted the importance of photosynthetic microorganisms and labile organic matter (polysaccharides) in the development of stable cryoconite granules. Indeed, Takeuchi et al. (2010) showed that environments rich in filamentous cyanobacteria promote the development of highly stable, large granules with visible quasi-annual growth layers.

The study of the concentration and composition of both carbohydrate and pigment concentrations within cryoconite has received limited research attention (e.g. Stibal et al., 2008, 2010; Yallop et al., 2012). However, within the fields of soil science and microbial ecology, the quantity of related research has been far greater. Carbohydrates, along with other low molecular weight organic molecules, play an important role in nutrient cycling (Fischer et al., 2007) and are instrumental in the formation and stabilisation of soil microaggregates (Cheshire et al., 1979; Oades, 1984, Puget et al., 1999). There is a strong correlation between labile carbohydrates and aggregate stability in agricultural soils (Tisdall, 1994; Puget et al., 1999). In certain sediments, a significant proportion of carbohydrates are microbially sourced extracellular polymeric substances (EPS). EPS is a labile and absorptive matrix, the production and composition of which depends upon the nutrient status and growth phase of the biota involved (Decho, 1990; Decho and Lopez, 1993). Cyanobacterial EPS has been found to be particularly complex (De Phillipis and Vincenzini, 1998; Pereira et al., 2009). In low-nutrient environments, EPS production can, perhaps surprisingly, be stimulated (Myklestad and Haug, 1972), particularly in phototrophic microorganisms (Ortega-Calvo and Stal, 1994). Furthermore, EPS has been found to actively promote flocculation and aggregation (Bar-Or and Shilo, 1988; Zulpa de Caire et al., 1997). Considering these factors, it is important to identify glacier-wide variability in carbohydrate production, as carbohydrates may control the formation of aggregates upon glaciers and ice sheets (e.g. Hodson et al., 2010; Stibal et al., 2010).

When carbohydrate contents and pigment contents (as a proxy for the number of photosynthetic microorganisms present) co-exist in substantial amounts, they are found to significantly increase the threshold of shear stress required for sediment erosion by flowing water (Underwood and Paterson, 1993; Sutherland et al., 1998a). Pigment contents, principally chlorophyll $a$, have long been utilised as biomarkers for phototrophic activity in soils and sediments (e.g. Swain, 1985; Downing and Rath, 1988). The useful- ness of chlorophyll $a$ comes from its prevalence amongst photosynthetic microorganisms, from algae and diatoms to cyanobacteria; indeed it is now regularly employed within glacial studies as a biomarker (Stibal et al., 2010; Morato et al., 2011). Whilst chlorophyll $a$ is a good general biomarker, the importance of additional biomarkers, in order to measure the abundance and distribution of particular photoautotrophs, should not be underestimated (Stewart and Farmer, 1984). Cyanobacteria are prevalent within glacial locations (Vincent, 2007) and produce a suite of water-soluble, motile phycobiliproteins (Wildman and Bowen, 1974), chiefly comprising phycoerythrin, phycocyanin and allophycocyanin. Their usefulness as biomarkers is in the fact that they are considered a more reliable proxy for cyanobacterial biomass (Lee et al., 1994; Lawrenz et al., 2011), and the fact that they are more responsive to environmental conditions (Grossman et al., 1993), meaning that their quantification, when compared against other environmental variables, may provide useful information on such environmental responses as photo-acclimation and bloom formation (Lawrenz et al., 2011).

Recent research into the biogeochemistry of cryoconite has focused on the concentration and composition of organic carbon (Stibal et al., 2010; Xu et al., 2009), and the concentration of chlorophyll $a$ (Foreman et al., 2007). Phycobiliprotein concentrations have been under-studied, with only Sattler et al. (2010) exploring this avenue, utilising laserinduced fluorescence imagery to study cyanobacterial autofluorescence within ice core debris. Whilst this research has highlighted the sparse application of some techniques such as ion chromatography and nuclear magnetic resonance spectroscopy, research has focused on isolated samples or transects. Given the lack of two-dimensional coverage, little can be understood regarding the supraglacial biogeography of these key environmental biomarkers. Furthermore, whilst research has evidenced photosynthesis within cryoconite (e.g. Säwström et al., 2002; Anesio et al., 2010; Hodson et al., 2010, Telling et al., 2010), more reliable values for nondegraded chlorophyll concentrations could enable photosynthesis to be normalised for chlorophyll. This would allow us to gain a greater insight into the efficiency of photosynthesis within cryoconite granules.

The objective of this paper is therefore to investigate the spatial variations in key biochemical aggregate-forming factors across an entire ablation zone, and to assess their control, versus the physics of their environment, over aggregate size and stability. Given the variability of cryoconite microstructure between Arctic glaciers (Langford et al., 2010), and the development of niche communities and microenvironments (Edwards et al., 2013; Zarsky et al., 2013), even on adjacent glaciers, care must be taken as to the wider representativeness of the data analysed and discussed henceforth. This research employs a spectrophotometric approach, using 96-well plates and performing a variety of assays, to allow rapid, glacierwide determination of specific biochemical parameters - in 


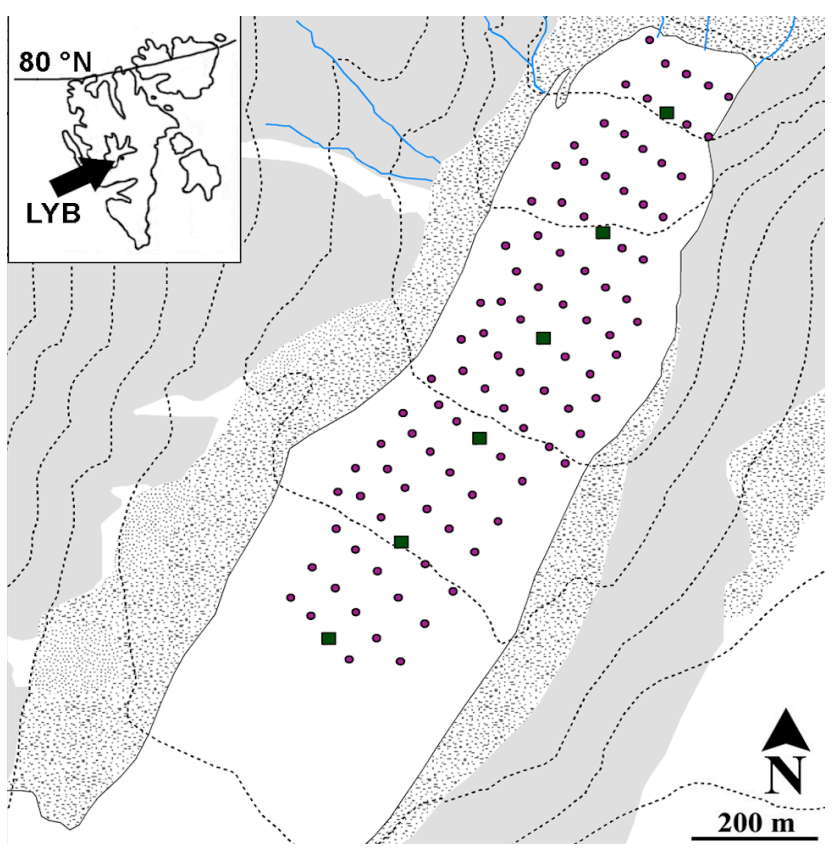

Figure 1. Longyearbreen (LYB) glacier showing sample grid (circles) and centre-line transect location (squares); the inset shows the location in the Svalbard Archipelago.

this case carbohydrate, chlorophyll $a$ and phycobiliprotein concentrations.

\section{Field site and methods}

\subsection{Field site and sampling strategy}

Fieldwork was undertaken on Longyearbreen glacier, Svalbard $\left(78^{\circ} 10^{\prime} 49^{\prime \prime} \mathrm{N}, 15^{\circ} 30^{\prime} 21^{\prime \prime} \mathrm{E}\right)$, in July 2010. The northeast-facing glacier has an area of $\sim 2.5 \mathrm{~km}^{2}$ ranging from $\sim 250 \mathrm{~m}$ to $\sim 1000 \mathrm{~m}$ a.s.l., with a mean width of approximately $500 \mathrm{~m}$. With an average ice depth of only $53 \mathrm{~m}$, Longyearbreen is thought to be cold-based, perhaps with the exception of a thin temperate ice zone in the accumulation area (Etzelmuller et al., 2000). The glacier is thinning at a rate of approximately $0.5 \mathrm{~m} \mathrm{a}^{-1}$ (Nuth et al., 2010) and the ablating ice surface comprises large amounts of cryoconite debris (Hodson et al., 2010; Irvine-Fynn et al., 2010). The glacier's catchment is set within a geology of coal-bearing shales, siltstones and sandstones (Yde et al., 2008).

Samples of cryoconite were collected using a gridded sampling design (Fig. 1; circles) extending $\sim 2 \mathrm{~km}$ from the glacier terminus to the transient snow line. The grid had a typical spacing of $100 \mathrm{~m}$ between points, given surface topographical constraints, and was constructed to enable the spatial mapping of resultant biogeochemical data. Four samples of cryoconite debris were abstracted from the nearest patch or hole to each grid point, to negate spatial bias. Digital pictures of the in situ cryoconite debris were taken at each sampling point using a consumer-grade 7.1 Megapixel digital camera, at a distance of $0.3 \mathrm{~m}$. Additional biogeochemical data were collected from six locations along a centre-line transect (Fig. 1; squares) in order to more comprehensively explore environmental predictors for aggregate size and stability.

Samples comprising $\sim 0.2 \mathrm{~mL}$ of cryoconite granules were collected in $1.8 \mathrm{~mL}$ cryovials, using pre-sterilised implements; these were then kept frozen at $-20^{\circ} \mathrm{C}$ and transported back to the UK on ice. In the laboratory, the frozen cryoconite samples were defrosted for further biogeochemical analyses, detailed below. Following these analyses, to account for the likely variation in cryoconite granule size, composition, and packing density, the samples were dried at $37^{\circ} \mathrm{C}$ and dry weight measurements were recorded.

\subsubsection{Carbohydrate extraction and analysis}

Carbohydrates were extracted using a dilute hot acid extraction, whereby $1.0 \mathrm{~mL}$ of $0.5 \mathrm{M}$ sulphuric acid $\left(\mathrm{H}_{2} \mathrm{SO}_{4}\right)$ was added to each vial, containing $\sim 0.2 \mathrm{~mL}$ of cryoconite granules, and these vials were shaken at $400 \mathrm{rpm}$ in an $80^{\circ} \mathrm{C}$ water bath for $2 \mathrm{~h}$. Following this, the vials were centrifuged at maximum speed for $10 \mathrm{~min}$ and $50 \mu \mathrm{L}$ of supernatant was removed from each vial and transferred into a well of a 96well microplate. A microplate version (Masuko et al., 2005) of the phenol-sulphuric acid method (Dubois et al. 1951) for the colorimetric determination of carbohydrate content was employed. Following the protocol of Masuko et al., $150 \mu \mathrm{L}$ of concentrated (18 M) $\mathrm{H}_{2} \mathrm{SO}_{4}$ and $30 \mu \mathrm{L}$ of $5 \%$ phenol (aq.) were added to each well in quick succession. The microplate was then incubated on a shallow tray of quartz sand, on a hot plate in a standard laboratory fume cupboard, at $90^{\circ} \mathrm{C}$ for $5 \mathrm{~min}$, before being cooled on an ice pack for $5 \mathrm{~min}$. The base of the microplate was dried and the absorbance measured at $490 \mathrm{~nm}$ on a Synergy 2 microplate reader. Triplicate readings were taken. Average values were calculated for each sampling point; concentration $\left(\mu \mathrm{g} \mathrm{g}^{-1}\right)$ was calculated based upon a standard curve of concentration versus absorbance for D-mannose (Sigma-Aldrich). Blanks of solely ultra-high quality water, and of ultra-high quality water with phenol and sulphuric acid, were run to determine the baseline for absorbance measurements.

\subsection{Chlorophyll extraction and analysis}

Methanol was used as an extractant, due to its high extraction efficiency and short processing time (Holm-Hansen and Riemann, 1978; Sartory and Grobbelaar, 1984; Thompson et al., 1999). A microplate technique (Warren, 2008) was again employed. To the cryovials containing $\sim 0.2 \mathrm{~mL}$ of cryoconite, $1.0 \mathrm{~mL}$ of methanol and $0.1 \mathrm{~g}$ of $0.5 \mathrm{~mm}$ glass bead-beating beads were added. The vials were first shaken in a bead beater for $1 \mathrm{~min}$, to disrupt the cellular component, before being vortexed for $2 \mathrm{~min}$ in the dark. Following 
this, the vials were centrifuged at maximum speed for $10 \mathrm{~min}$ and $200 \mu \mathrm{L}$ of each supernatant removed to a well of a 96-well microplate. Absorbance spectra were measured, between $300 \mathrm{~nm}$ and $750 \mathrm{~nm}$, on a Synergy 2 microplate reader. Triplicate readings were taken. Average values were calculated for each sampling point; concentration $\left(\mu \mathrm{g} \mathrm{g}^{-1}\right)$ was calculated based upon a standard curve of concentration versus absorbance for chlorophyll $a$ (e.g. Porra et al., 1989) from spinach (Sigma-Aldrich). Blanks consisting solely of methanol were run to determine the baseline for absorbance measurements.

\subsection{Phycobiliprotein extraction and analysis}

A combined physical and chemical extraction technique was utilised, as this has previously been found to achieve the greatest cell disruption and extraction efficiency (Lawrenz et al., 2011). Each cryovial, containing $\sim 0.2 \mathrm{~mL}$ of cryoconite and $0.5 \mathrm{~mL}$ of phosphate buffer, was subjected to three freeze-thaw cycles in liquid nitrogen for $30 \mathrm{~s}$ and then on dry ice for $15 \mathrm{~min}$, followed by ice for $15 \mathrm{~min}$. Following this, $0.5 \mathrm{~mL}$ of a $2 \times$ lysozyme-EDTA solution was added to achieve a working concentration of $1 \mathrm{mg} \mathrm{mL}^{-1}$ lysozyme and $50 \mathrm{mM}$ Na-EDTA. The cryovials were then incubated at $37^{\circ} \mathrm{C}$ for $30 \mathrm{~min}$, before being cooled to $4{ }^{\circ} \mathrm{C}$. Finally, the cryovials were homogenised in a bead beater for $60 \mathrm{~s}$, before being left to stand for $96 \mathrm{~h}$, with one change of supernatant after $48 \mathrm{~h}$. Of the resultant $2 \mathrm{~mL}$ of supernatant, $200 \mu \mathrm{L}$ of each sample was added to a 96-well microplate and fluorescence measured on a Synergy 2 microplate reader using the 590/35 emission filter. Average values were calculated for each sampling point; concentration $\left(\mu \mathrm{g} \mathrm{g}^{-1}\right)$ was calculated based upon a standard curve of concentration versus fluorescence for phycocyanin (Sigma-Aldrich). Blanks of phosphate-buffered ultra-high quality water were also run, to provide a baseline for fluorescence measurements.

\subsection{Image analysis}

The analysis of field-based imagery for Longyearbreen was performed using Image $\mathrm{J}^{\mathrm{TM}}$. Each image was first scaled to determine and define the pixel resolution. Subsequently, images were manually processed using the elliptical selection and measurement tools; for each grid point, a minimum of 50 cryoconite granules were sized and the transverse diameter of the ellipse recorded. The mean average of these diameter values was then calculated, providing an average aggregate diameter value for the cryoconite granules within each image.

\subsection{Supplementary environmental data}

To discern environmental data for each sample point, a digital elevation model (DEM) of Longyearbreen (sourced from the Norwegian Polar Institute), with a horizontal resolution of $20 \mathrm{~m}$, was interrogated using ESRI's ArcGIS. Glacier surface parameters including elevation, slope and aspect were retrieved. Cumulative potential incident radiation $\left(\mathrm{kW} \mathrm{h} \mathrm{m}^{-2}\right)$ receipt (hereafter IR receipt) over the ablation season was estimated using ArcGIS's Solar Analysis module. Specifically, (i) automated weather station data from Gruvefjellet, (approximately $2.5 \mathrm{~km}$ from the Longyearbreen ablation area and at $400 \mathrm{~m}$ ), was used to define the duration of the ablation season from continuously positive air temperatures, corrected to exclude the typical snowmelt duration (Bruland et al., 2001); (ii) given typical summer cloudiness in western Svalbard (Hanssen-Bauer et al., 1990) the "overcast sky" option was employed; (iii) a mean atmospheric transmissivity $(t)$ of 0.63 was used (after the formulation given by Kreith and Kreider, 1978; see Irvine-Fynn et al., 2012a); and (iv) estimates of IR receipt calculated at $30 \mathrm{~min}$ intervals were summed for the ablation season.

\subsection{Supplementary biogeochemical data}

Using six of the grid points (marked with squares in Fig. 1), a centre-line transect was devised. Data from the spatial mapping data set relating to these six grid points were plotted alongside additional biogeochemical data obtained for these six grid points - namely organic matter content, aggregate stability, net ecosystem production and respiration, and both the number and characteristics of photoautotrophs within the samples. In the laboratory, the organic matter content of the cryoconite debris was measured, in triplicate, using a Shimadzu Total Organic Carbon analyser following an overnight $0.1 \mathrm{M} \mathrm{NaOH}$ extraction at a 1:5 solid-liquid ratio; alkaline extraction is a standard and commonly used procedure shown to extract a high proportion of the organic matter within soil samples (Schnitzer, 1982). A UV/Vis absorbance curve ensured that maximum extraction yield was reached within the $18 \mathrm{hr}$ extraction period. Aggregate stability was measured photographically using image analysis. For each sample, a $100 \mathrm{mg}$ sub-sample was imaged and average granule diameter was measured using Image ${ }^{\mathrm{TM}}$, as detailed previously. Following this, each sample was agitated by vortexing for $30 \mathrm{~s}$ and re-imaged, with average granule diameter once again measured. Considering the fraction $>250 \mu \mathrm{m}$ to be the stable macroaggregate fraction (Tisdall and Oades, 1982; Puget et al., 1999), the percentage of aggregates $>250 \mu \mathrm{m}$ after agitation versus before agitation was calculated and used as a simple indicator of aggregate stability. Net ecosystem productivity and respiration were measured in triplicate using the $\triangle$ TDIC method of Hodson et al. (2010), including correction for carbonate dissolution. Photoautotroph total counts were performed on $10 \mathrm{mg}$ of disaggregated cryoconite, at $400 \times$ magnification, on a Zeiss Axioplan 2 epifluorescence microscope using autofluorescent emission and a Cy5 filter cube; images were recorded with a colour CCD camera. The numbers of filamentous and unicellular photoautotrophs were counted separately across five fields of view, in triplicate, for each of the six samples. In addition, within 
Image $^{\mathrm{TM}}, 50$ random measurements of filament length were made from the above images, for each sample; these measurement were taken manually using the line measurement tool and excluded any filaments that touched the edge of the field of view or were obstructed by opaque material. From these data, average filament length values for each sample could then be multiplied by the filamentous photoautotroph count to obtain an estimate of filament length per gram of cryoconite.

\subsection{Statistical analyses}

Canonical correlation analysis (CCA) was employed to explore the variability within the gridded spatial data; CCA is a multivariate constrained ordination technique used to measure the relationships between the observed values of two or more sets of variables (Clark, 1975). All analyses were performed using the MultiVariate Statistical Package, by Kovach Computing Services, Anglesey, UK. In order to explore the centre-line transect data in relation to aggregate size and stability, multivariate linear regression analysis was applied in SPSS v. 19, using aggregate size and stability as dependent variables, and all other biogeochemical and physical parameters as predictors. When using one dependent variable, multivariate linear regression was conducted using a stepwise multivariate approach, with $P<0.05$ as the selector. When using two dependent variables, multivariate linear regression was run as a full factorial model, with Type III sums of squares.

\section{Results}

\subsection{Spatial mapping of biogeochemical parameters}

Table 1 shows the basic statistics for the biogeochemical parameters sampled across the ablation zone of Longyearbreen. For each parameter (carbohydrate, chlorophyll $a$ and phycobiliprotein concentrations, and aggregate size) and grid point, mean average values were utilised when undertaking spatial mapping. For visualisation, mean concentration data, mean aggregate size data and IR receipt were plotted as contour maps (Fig. 2). Various interpolation routines were investigated and a multiquadric radial basis function (Hardy, 1971) was chosen, using nine neighbours, as it yielded the lowest root mean square values $(<1.455)$ and adheres to the source data.

Carbohydrate concentrations varied across the Longyearbreen ablation zone at the time of sampling (Fig. 2a). A maximum monosaccharide concentration of $7.89 \mu \mathrm{g} \mathrm{g}^{-1}$ dry weight (dw) of cryoconite was detected in the region closest to the snow line, supporting the general trend of greater average carbohydrate concentrations up-glacier. The variability in chlorophyll $a$ concentrations, as visualised in Fig. 2b, showed a greater degree of spatial heterogeneity, though the greater concentrations were present nearer to the valley sides

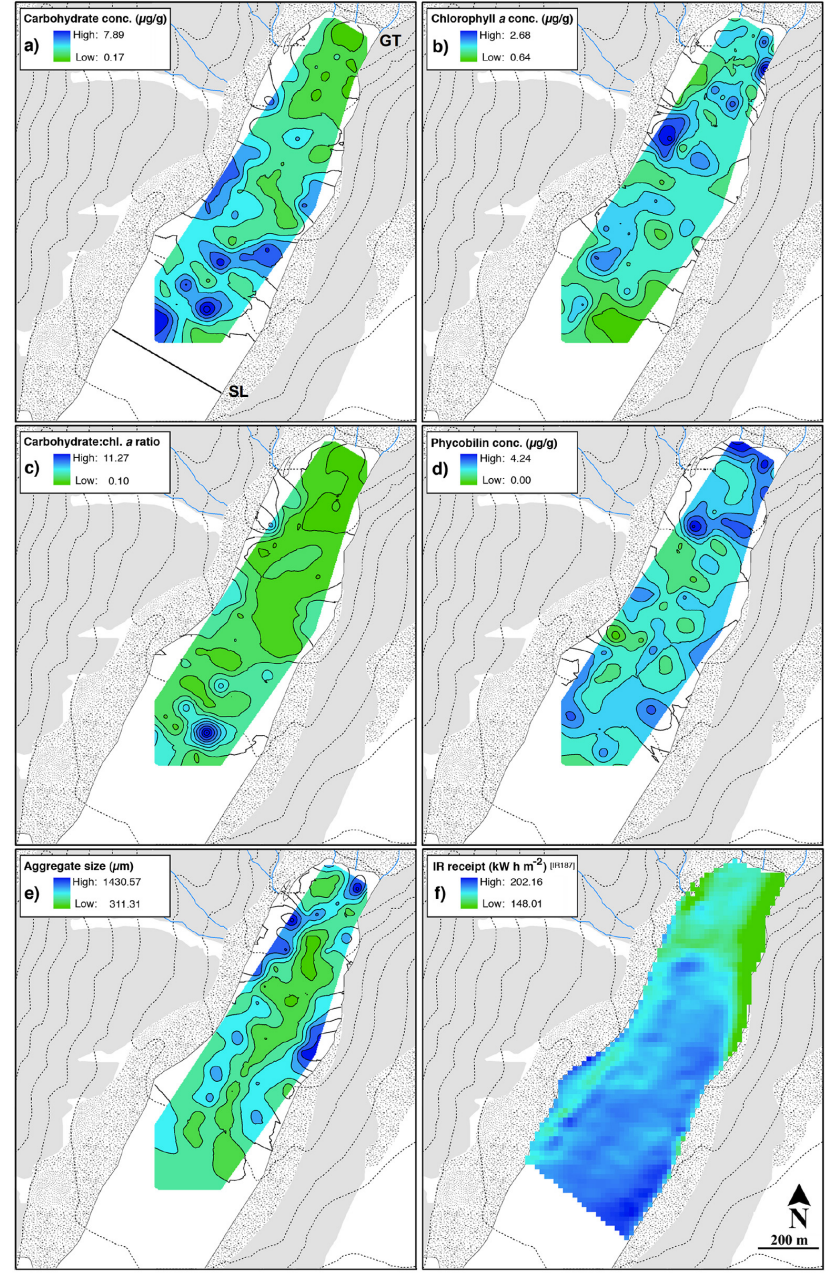

Figure 2. Variation of biogeochemical parameters across Longyearbreen ablation zone - interpolated maps showing: (a) carbohydrate concentration ( $\mu \mathrm{g} \mathrm{g}^{-1} \mathrm{dw}$ cryoconite), (b) chlorophyll $a$ concentration ( $\mu \mathrm{g} \mathrm{g}^{-1} \mathrm{dw}$ cryoconite), (c) the carbohydrate/chlorophyll ratio, (d) phycobiliprotein concentration $\left(\mu \mathrm{g} \mathrm{g}^{-1} \mathrm{dw}\right.$ cryoconite), (e) cryoconite aggregate size $(\mu \mathrm{m})$, and (f) cumulative predicted incident radiation receipt $\left(\mathrm{kW} \mathrm{h} \mathrm{m}^{-2}\right)$, presented as continuous raster dataGT, glacier terminus; SL, snow line.

and glacier terminus, reaching a maximum of $2.68 \mu \mathrm{g} \mathrm{g}^{-1}$ dw. The contrast between carbohydrate and chlorophyll $a$ concentrations is further visualised when the carbohydrate:chlorophyll ratio is contour-mapped (Fig. 2c), exhibiting excesses of carbohydrate up-glacier, exceeding $11 \times$ the corresponding chlorophyll $a$ concentration at its highest. Phycobiliprotein concentrations showed a more mixed picture (Fig. 2d), though the greatest concentrations, as with chlorophyll $a$, were found proximate to the glacier terminus, reaching $4.24 \mu \mathrm{g} \mathrm{g}^{-1} \mathrm{dw}$.

Aggregate size (Fig. 2e) showed perhaps the greatest variability between locations, varying between $<300 \mu \mathrm{m}$ and ca. $1.5 \mathrm{~mm}$. Aggregate size was greatest, at the time of 
Table 1. Summary table for all spatial data collected.

\begin{tabular}{lccccc}
\hline Parameter & Max. & Min. & Mean & Median & Standard Deviation \\
\hline $\begin{array}{l}\text { Carbohydrate } \\
\text { concentration }\left(\mu \mathrm{gg}^{-1}\right)\end{array}$ & 7.89 & 0.17 & 2.92 & 2.73 & 1.54 \\
\hline $\begin{array}{l}\text { Chlorophyll } a \\
\text { concentration }\left(\mu \mathrm{gg}^{-1}\right)\end{array}$ & 2.68 & 0.64 & 1.38 & 1.34 & 0.40 \\
\hline Phycobiliprotein & 4.24 & 0.00 & 2.06 & 2.00 & 0.73 \\
concentration $\left(\mu \mathrm{gg}^{-1}\right)$ & & & & & \\
\hline Aggregate size $(\mu \mathrm{m})$ & 1430.57 & 311.31 & 721.79 & 695.70 & 225.27 \\
Slope $(\%)$ & 12.89 & 4.77 & 7.40 & 6.88 & 1.64 \\
Aspect $\left({ }^{\circ}\right)$ & 68.54 & 3.19 & 30.75 & 31.57 & 14.94 \\
\hline Incident radiation receipt & 202.16 & 148.01 & 192.03 & 194.28 & 9.44 \\
$\left(\right.$ IR $\left.187, \mathrm{~kW} \mathrm{~h} \mathrm{~m}^{-2}\right)$ & & & & & \\
\hline
\end{tabular}

sampling, towards the edges of the glacier and, though not as pronounced, towards the glacier terminus. Furthermore, to a greater extent than the other three parameters mapped, a central zone of lower values is visible on the contour map. A lower mean aggregate size was present in that region at the time of sampling, with aggregate size not exceeding $600 \mu \mathrm{m}$.

Glacier surface parameters (Table 1) show some variability across the Longyearbreen ablation zone, with slope varying from ca. $5^{\circ}$ to ca. $13^{\circ}$ and aspect varying from ca. $3^{\circ}$ to ca. $69^{\circ}$, though low standard deviations indicate a relative surface homogeneity at the $20 \mathrm{~m}$ scale of the DEM. Some spatial variability in IR receipt $\left(\mathrm{kW} \mathrm{h} \mathrm{m}^{-2}\right)$, for the summer ablation season, is evident across the glacier surface (Fig. 2f). The southeast portion of the ablation area received the most IR and the northeast corner received substantially less than elsewhere, due to shading effects from the surrounding upland areas. It is noticeable, however, that, at the glacier scale, IR receipt was relatively similar across the upper two-thirds of the ablation zone (standard deviation of $9.44 \mathrm{~kW} \mathrm{~h} \mathrm{~m}^{-2}$ ).

Punctuating these general trends, "hotspots" can be visualised on most of the maps in Fig. 2, generally tending towards the outer edges of the ablation zone. In addition to those associated with the general trends, hotspots of high carbohydrate concentration were detected midway down the northwestern and southeastern edges of the ablation zone; some hotspots with high chlorophyll $a$ were detected upglacier along the northwestern edge; hotspots of high phycobiliprotein concentration were also detected along this edge, with some further hotspots evident up-glacier along the southeastern edge. These hotspots emphasise the spatial heterogeneity of the data and underline the need for statistical investigation.

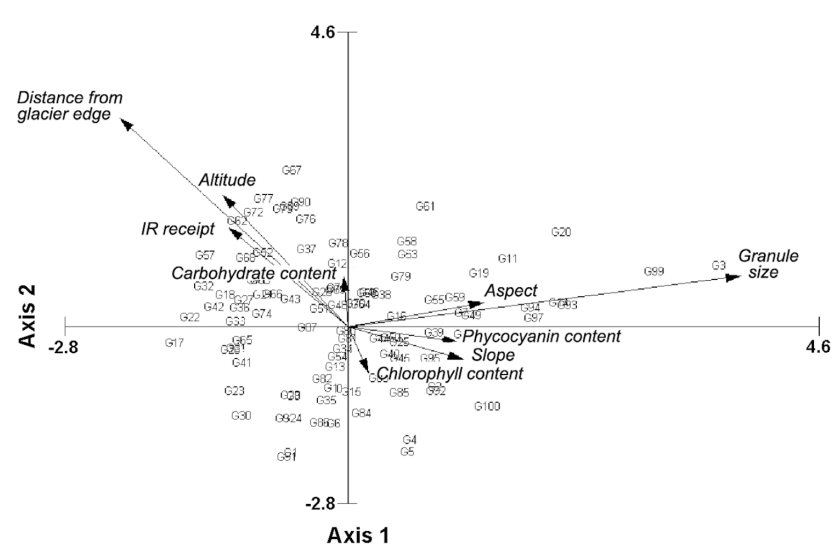

Figure 3. CCA bi-plots for both the (a) physical and (b) biogeochemical data relating to the sample grid.

\subsection{Comparison of spatial data}

When visually comparing the spatial data presented in Fig. 2, some similarities and differences can be noted. Pigment concentrations, as with aggregate size and conversely to carbohydrate concentrations, showed greater values proximate to the glacier terminus - however, spatial heterogeneity led to a consequent lack of strong spatial trends regarding photosynthetic pigments. Certain hotspots of aggregate size can be visually correlated with hotspots in pigment concentrations, whilst a correlation with carbohydrate hotspots is less evident. Additionally, IR receipt might have been expected to show a similar spatial distribution to that shown by chlorophyll $a$ concentrations, yet an inverse relationship seems to exist, with the carbohydrate:chlorophyll ratio indicating that, in general, areas of higher IR receipt had a higher carbohydrate content and lower chlorophyll $a$ content. 
In order to statistically differentiate the sampling points in terms of their physical and biogeochemical parameters, and thus emphasise any variability, CCA was employed. Figure 3 shows the CCA bi-plot for the gridded biogeochemical and physical data. Overall, the first two axes explain $89 \%$ of the variance in the data, with the first axis explaining $74 \%$ of this variance. The data are not tightly clustered around the centre-point, indicating variability between sampling points. Intraset correlations indicate that the greatest positive correlations for the first axis are granule size (0.967) and aspect (0.334), with the two showing a degree of collinearity, whilst the greatest negative correlations are distance from glacier edge $(-0.562)$ and altitude $(-0.308)$. The second axis is positively correlated with distance from glacier edge $(0.823)$ and altitude (0.518), and negatively correlated with chlorophyll $a$ concentration $(-0.183)$ and slope $(-0.128)$.

In general, CCA indicates that up-glacier and glacier interior sampling points have greater IR receipt and carbohydrate contents, whilst down-glacier and glacier edge sampling points, showing a different aspect, have greater pigment contents and larger granule sizes. As such, whilst the biochemical data in particular appear to show a greater degree of statistical uniformity than for similar data relating to larger ice masses (e.g. Stibal et al., 2011, 2012), the data as a whole does indicate a degree of down-glacier biogeochemical and photophysical evolution, a fact that warranted further specific investigation.

\subsection{Environmental influences over aggregate size and stability}

With spatial mapping allowing the visualisation of some significant supraglacial variability in biogeochemical and physical parameters (Figs. 2 and 3), particularly down-glacier, further investigation focused on a centre-line transect through the Longyearbreen study area and incorporated supplementary environmental information, providing a data set for correlation and multivariate linear regression, in order to statistically deduce the principal factor(s) affecting cryoconite aggregate size and stability. Figure 4 shows the principal biogeochemical data for this centre-line transect and Table 2 shows the Pearson correlation matrix for this data.

Along the glacier transect, aggregate size and stability (Fig. 4a) were well correlated $(r=0.768 ; P=0.075)$. Near to both the glacier terminus and the snow line, aggregate size and stability were at their greatest, with a generally stable average aggregate size evident otherwise. Significant correlations between the filamentous photoautotroph count and filament length parameters and both aggregate size and stability exist (Table 2). The organic matter content of the cryoconite granules (Fig. $4 \mathrm{~b})$ shows a negative linear trend $\left(r^{2}=\right.$ 0.976 ) with distance up-glacier, falling from $176.50 \mathrm{mg} \mathrm{g}^{-1}$ to $127.85 \mathrm{mg} \mathrm{g}^{-1}$. This is in complete contrast with carbohydrate content (Fig. 4b), which increases up-glacier from $0.816 \mu \mathrm{g} \mathrm{g}^{-1}$ to $2.662 \mu \mathrm{g} \mathrm{g}^{-1}$ and shows a significant neg-

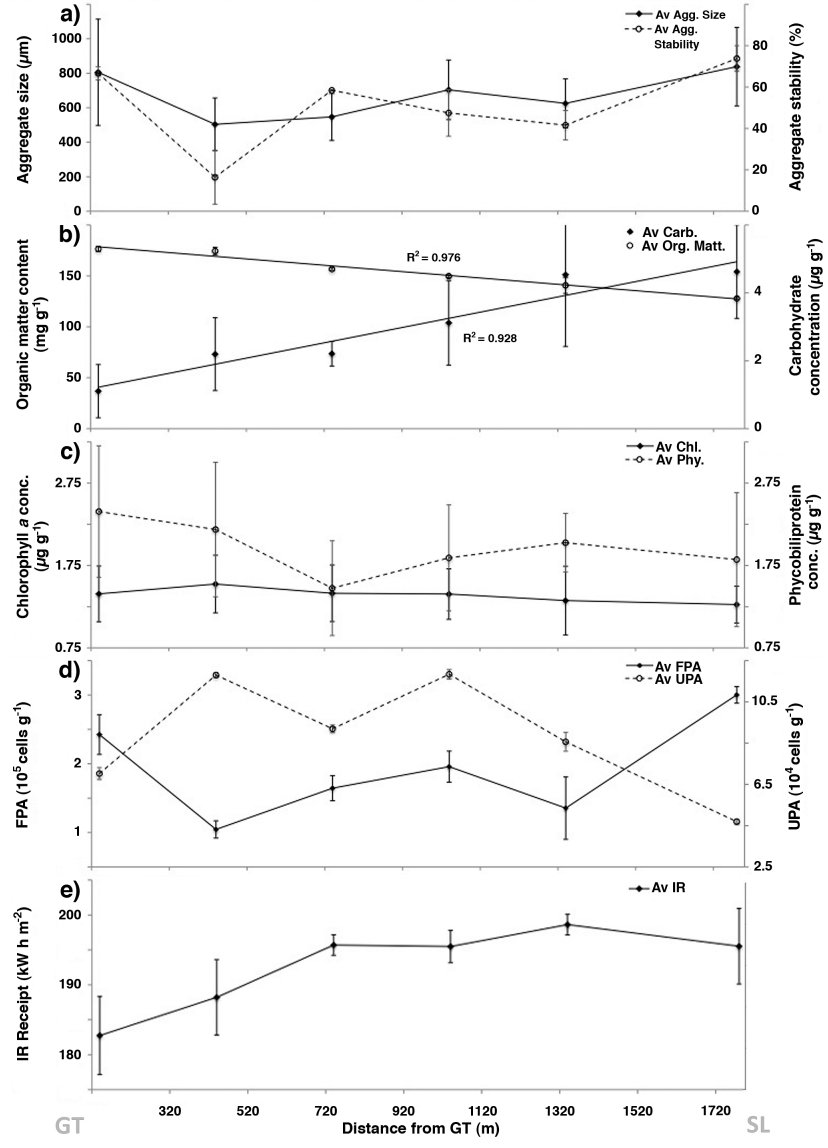

Figure 4. Glacier centre-line transect data, summarising biogeochemical data between glacier terminus (GT) and snow line (SL), detailing variation in: (a) aggregate size $(\mu \mathrm{m})$ and stability $(\%)$; (b) organic matter content $\left(\mathrm{mg} \mathrm{g}^{-1}\right)$ and labile carbohydrate content $\left(\mu \mathrm{gg}^{-1}\right)$; (c) chlorophyll $a$ concentration $\left(\mu \mathrm{gg}^{-1}\right)$ and phycobiliprotein concentration $\left(\mu \mathrm{g} \mathrm{g}^{-1}\right)$; (d) unicellular photoautotroph count $\left(10^{4}\right.$ cells $\left.\mathrm{g}^{-1}\right)$ and filamentous photoautotroph count $\left(10^{5}\right.$ cells $\left.\mathrm{g}^{-1}\right)$; and (e) cumulative predicted incident radiation receipt $\left(\mathrm{kW} \mathrm{h} \mathrm{m}^{-2}\right)$; error bars show standard deviation.

ative correlation with organic matter content $(r=-0.931$, $P=0.007)$.

Transect data for chlorophyll $a$ and phycobiliprotein concentrations (Fig. 4c) did not indicate a statistically significant down-glacier trend, thus only serving to illustrate the ubiquitous presence of photoautotrophic microorganisms across the glacier. These data also illustrate the benefit of spatial mapping, given that spatial statistics (Fig. 3) indicated that pigment concentrations were both inversely correlated with distance from the glacier edge and altitude, and potentially driven by the heterogeneity of the glacier's weathering crust environment. The phototrophic content of cryoconite (Fig. 4d), when broken down into unicellular and filamentous photoautotroph counts and filament length parameters, varies considerably more than the phycobiliprotein concentrations. The filamentous photoautotroph count 
Table 2. Correlation matrix for all transect data collected; significant correlations are emboldened; NEP $=$ net ecosystem productivity, $\mathrm{FPA}=$ filamentous photoautotrophs, UPA = unicellular photoautotrophs, FLPG = filament length per granule, CCR $=$ carbohydrate chlorophyll ratio, and $\mathrm{CPR}=$ carbohydrate-phycobilin ratio.

\begin{tabular}{|c|c|c|c|c|c|c|c|c|c|c|c|c|c|c|c|c|}
\hline & Agg. size & $\begin{array}{l}\text { Agg. } \\
\text { stability }\end{array}$ & NEP & Resp. & $\begin{array}{c}\mathrm{OM} \\
\text { content }\end{array}$ & $\begin{array}{l}\text { Carb. } \\
\text { content }\end{array}$ & $\begin{array}{l}\text { Chl. } a \\
\text { content }\end{array}$ & $\begin{array}{l}\text { Phyco- } \\
\text { bilin } \\
\text { content }\end{array}$ & FPA & UPA & FLGP & $\mathrm{CCR}$ & CPR & Slope & Aspect & IR \\
\hline \multicolumn{17}{|l|}{$\begin{array}{l}\text { Aggregate } \\
\text { size }\end{array}$} \\
\hline $\begin{array}{l}\text { Aggregate } \\
\text { stability }\end{array}$ & $\begin{array}{c}0.768 \\
(0.075)\end{array}$ & & & & & & & & & & & & & & & \\
\hline NEP & $\begin{array}{c}0.169 \\
(0.750)\end{array}$ & $\begin{array}{c}0.189 \\
(0.719)\end{array}$ & & & & & & & & & & & & & & \\
\hline Respiration & $\begin{array}{c}0.694 \\
(0.126)\end{array}$ & $\begin{array}{c}0.353 \\
(0.493)\end{array}$ & $\begin{array}{l}-0.199 \\
(0.705)\end{array}$ & & & & & & & & & & & & & \\
\hline $\begin{array}{l}\text { Organic matter } \\
\text { content }\end{array}$ & $\begin{array}{l}-0.359 \\
(0.484)\end{array}$ & $\begin{array}{l}-0.400 \\
(0.432)\end{array}$ & $\begin{array}{l}-0.194 \\
(0.713)\end{array}$ & $\begin{array}{l}-0.680 \\
(0.137)\end{array}$ & & & & & & & & & & & & \\
\hline $\begin{array}{l}\text { Carbohydrate } \\
\text { content }\end{array}$ & $\begin{array}{c}0.192 \\
(0.716)\end{array}$ & $\begin{array}{c}0.088 \\
(0.868)\end{array}$ & $\begin{array}{l}-0.008 \\
(0.988)\end{array}$ & $\begin{array}{c}0.729 \\
(0.100)\end{array}$ & $\begin{array}{l}\mathbf{- 0 . 9 3 1} \\
(0.007)\end{array}$ & & & & & & & & & & & \\
\hline $\begin{array}{l}\text { Chlorophyll } a \\
\text { content }\end{array}$ & $\begin{array}{l}-0.670 \\
(0.145)\end{array}$ & $\begin{array}{l}-0.704 \\
(0.118)\end{array}$ & $\begin{array}{c}0.035 \\
(0.948)\end{array}$ & $\begin{array}{l}-0.783 \\
(0.066)\end{array}$ & $\begin{array}{c}\mathbf{0 . 8 5 9} \\
(0.029)\end{array}$ & $\begin{array}{l}-0.734 \\
(0.097)\end{array}$ & & & & & & & & & & \\
\hline $\begin{array}{l}\text { Phycobiliprotein } \\
\text { content }\end{array}$ & $\begin{array}{c}0.237 \\
(0.651)\end{array}$ & $\begin{array}{l}-0.264 \\
(0.614)\end{array}$ & $\begin{array}{l}-0.493 \\
(0.321)\end{array}$ & $\begin{array}{c}0.220 \\
(0.676)\end{array}$ & $\begin{array}{c}0.539 \\
(0.269)\end{array}$ & $\begin{array}{l}-0.342 \\
(0.507)\end{array}$ & $\begin{array}{c}0.263 \\
(0.615)\end{array}$ & & & & & & & & & \\
\hline FPA & $\begin{array}{c}\mathbf{0 . 9 3 3} \\
(0.007)\end{array}$ & $\begin{array}{c}\mathbf{0 . 8 7 7} \\
(0.022)\end{array}$ & $\begin{array}{c}0.293 \\
(0.573)\end{array}$ & $\begin{array}{c}0.588 \\
(0.219)\end{array}$ & $\begin{array}{l}-0.414 \\
(0.415)\end{array}$ & $\begin{array}{c}0.169 \\
(0.749)\end{array}$ & $\begin{array}{c}0.659 \\
(0.155)\end{array}$ & $\begin{array}{l}-0.027 \\
(0.959)\end{array}$ & & & & & & & & \\
\hline UPA & $\begin{array}{l}-0.724 \\
(0.104)\end{array}$ & $\begin{array}{l}-0.799 \\
(0.057)\end{array}$ & $\begin{array}{c}0.301 \\
(0.562)\end{array}$ & $\begin{array}{l}-0.687 \\
(0.132)\end{array}$ & $\begin{array}{c}0.456 \\
(0.363)\end{array}$ & $\begin{array}{l}-03.09 \\
(0.551)\end{array}$ & $\begin{array}{c}0.769 \\
(0.074)\end{array}$ & $\begin{array}{l}-0.024 \\
(0.964)\end{array}$ & $\begin{array}{l}-0.784 \\
(0.065)\end{array}$ & & & & & & & \\
\hline FLPG & $\begin{array}{c}\mathbf{0 . 9 4 6} \\
(0.004)\end{array}$ & $\begin{array}{c}\mathbf{0 . 8 4 8} \\
(0.033)\end{array}$ & $\begin{array}{c}0.255 \\
(0.626)\end{array}$ & $\begin{array}{c}0.432 \\
(0.393)\end{array}$ & $\begin{array}{l}-0.171 \\
(0.746)\end{array}$ & $\begin{array}{l}-0.071 \\
(0.894)\end{array}$ & $\begin{array}{l}-0.535 \\
(0.274)\end{array}$ & $\begin{array}{c}0.173 \\
(0.743)\end{array}$ & $\begin{array}{c}\mathbf{0 . 9 1 6} \\
(0.010)\end{array}$ & $\begin{array}{l}-0.651 \\
(0.162)\end{array}$ & & & & & & \\
\hline CCR & $\begin{array}{c}0.180 \\
(0.732)\end{array}$ & $\begin{array}{c}0.093 \\
(0.860)\end{array}$ & $\begin{array}{l}-0.144 \\
(0.786)\end{array}$ & $\begin{array}{c}0.732 \\
(0.098)\end{array}$ & $\begin{array}{l}-\mathbf{0 . 9 0 1} \\
(0.014)\end{array}$ & $\begin{array}{c}\mathbf{0 . 9 8 5} \\
(0.000)\end{array}$ & $\begin{array}{l}-0.761 \\
(0.079)\end{array}$ & $\begin{array}{l}-0.282 \\
(0.588)\end{array}$ & $\begin{array}{c}0.125 \\
(0.813)\end{array}$ & $\begin{array}{l}-0.344 \\
(0.504)\end{array}$ & $\begin{array}{l}-0.076 \\
(0.886)\end{array}$ & & & & & \\
\hline CPR & $\begin{array}{l}-0.020 \\
(0.970)\end{array}$ & $\begin{array}{c}0.037 \\
(0.944)\end{array}$ & $\begin{array}{c}0.216 \\
(0.680)\end{array}$ & $\begin{array}{c}0.429 \\
(0.396)\end{array}$ & $\begin{array}{l}-\mathbf{0 . 9 0 4} \\
(0.013)\end{array}$ & $\begin{array}{c}\mathbf{0 . 9 2 1} \\
(0.009)\end{array}$ & $\begin{array}{l}-0.610 \\
(0.199)\end{array}$ & $\begin{array}{c}-0.61 \\
(0.190)\end{array}$ & $\begin{array}{c}0.010 \\
(0.985)\end{array}$ & $\begin{array}{l}-0.063 \\
(0.905)\end{array}$ & $\begin{array}{c}0.203 \\
(0.700)\end{array}$ & $\begin{array}{c}\mathbf{0 . 8 9 2} \\
(0.017)\end{array}$ & & & & \\
\hline Slope & $\begin{array}{c}0.080 \\
(0.881)\end{array}$ & $\begin{array}{l}-0.321 \\
(0.534)\end{array}$ & $\begin{array}{l}-0.348 \\
(0.499)\end{array}$ & $\begin{array}{l}-0.119 \\
(0.822)\end{array}$ & $\begin{array}{c}0.779 \\
(0.068)\end{array}$ & $\begin{array}{l}-0.626 \\
(0.184)\end{array}$ & $\begin{array}{c}0.515 \\
(0.296)\end{array}$ & $\begin{array}{c}\mathbf{0 . 9 3 6} \\
(0.006)\end{array}$ & $\begin{array}{l}-0.154 \\
(0.771)\end{array}$ & $\begin{array}{c}0.200 \\
(0.703)\end{array}$ & $\begin{array}{c}0.120 \\
(0.821)\end{array}$ & $\begin{array}{l}-0.572 \\
(0.235)\end{array}$ & $\begin{array}{l}-0.795 \\
(0.059)\end{array}$ & & & \\
\hline Aspect & $\begin{array}{c}0.769 \\
(0.074)\end{array}$ & $\begin{array}{c}0.563 \\
(0.244)\end{array}$ & $\begin{array}{l}-0.323 \\
(0.532)\end{array}$ & $\begin{array}{c}0.784 \\
(0.065)\end{array}$ & $\begin{array}{l}-0.460 \\
(0.358)\end{array}$ & $\begin{array}{c}0.432 \\
(0.392)\end{array}$ & $\begin{array}{l}-0.807 \\
(0.052)\end{array}$ & $\begin{array}{c}0.316 \\
(0.541)\end{array}$ & $\begin{array}{c}0.578 \\
(0.230)\end{array}$ & $\begin{array}{l}-0.711 \\
(0.113)\end{array}$ & $\begin{array}{c}0.648 \\
(0.164)\end{array}$ & $\begin{array}{c}0.516 \\
(0.295)\end{array}$ & $\begin{array}{c}0.195 \\
(0.711)\end{array}$ & $\begin{array}{c}0.078 \\
(0.883)\end{array}$ & & \\
\hline $\begin{array}{l}\text { Incident radiation } \\
\text { (IR) receipt }\end{array}$ & $\begin{array}{l}-0.164 \\
(0.756)\end{array}$ & $\begin{array}{c}0.043 \\
(0.936)\end{array}$ & $\begin{array}{c}0.216 \\
(0.681)\end{array}$ & $\begin{array}{c}0.226 \\
(0.667)\end{array}$ & $\begin{array}{l}-\mathbf{0 . 8 2 9} \\
(0.042)\end{array}$ & $\begin{array}{c}\mathbf{0 . 8 1 2} \\
(0.050)\end{array}$ & $\begin{array}{l}-0.534 \\
(0.275)\end{array}$ & $\begin{array}{l}-0.747 \\
(0.088)\end{array}$ & $\begin{array}{l}-0.098 \\
(0.853)\end{array}$ & $\begin{array}{c}0.011 \\
(0.984)\end{array}$ & $\begin{array}{l}-0.282 \\
(0.588)\end{array}$ & $\begin{array}{c}0.797 \\
(0.058)\end{array}$ & $\begin{array}{c}\mathbf{0 . 9 6 8} \\
(0.002)\end{array}$ & $\begin{array}{l}-\mathbf{0 . 8 5 8} \\
(0.029)\end{array}$ & $\begin{array}{c}0.084 \\
(0.874)\end{array}$ & \\
\hline
\end{tabular}

shows some variability, with greater numbers present near to both the glacier terminus and the snow line (averaging ca. $3.0 \times 10^{5}$ cells $^{-1}$ ). Conversely, the unicellular photoautotroph count is nearly the inverse of the filamentous count ( $r=-0.784, P=0.065$ ). Interestingly, correlation analysis (Table 2) also shows a good correlation between the number of unicellular photoautotrophs and the chlorophyll $a$ concentration ( $r=0.769, P=0.074)$. The filament length data (not shown) are, as expected, similar in trend to the filament count data $(r=0.916, P=0.010)$. The main difference is that the greatest mean filament length was found in cryoconite closest to the glacier terminus $\left(2.46 \times 10^{7} \mu \mathrm{m} \mathrm{g}^{-1}\right)$.

When considering the photophysical parameters, namely IR receipt (Fig. 4e), slope and aspect, some further correlations with biogeochemical data exist. IR receipt broadly increases up-glacier and, as such, correlates well with carbohydrate content ( $r=0.812, P=0.050$ ). Interestingly, whilst slope positively correlates with phycobiliprotein concentration, aspect negatively correlates with chlorophyll $a$ concentration (Table 2). Although not all correlations between pig- ment concentrations and photophysical parameters are significant at the $P=0.05$ level, these correlation data indicate that lower-light, north-facing conditions favour pigment production and/or survival. Further strong correlations include positive correlations between microbial respiration and carbohydrate concentration and between aspect and aggregate size, along with a negative correlation between respiration and chlorophyll $a$ concentration; however, these failed to achieve statistical significance at the $P=0.05$ level.

In order to explore the above patterns and how they relate specifically to aggregate size and stability, multivariate linear regression analysis was applied to these centre-line transect data in SPSS v. 19. Considering aggregate size as the dependent variable, and utilising a stepwise approach, the only single parameter that showed a statistically significant relationship ( $P<0.05$ ) was filament length, which was found to explain $86.9 \%$ of the variation in aggregate size ( $P=0.004)$. Using backwards elimination, unicellular photoautotroph count, filamentous photoautotroph count and aspect were found to explain $95.5 \%$ of the measured variation 
in aggregate size $(P=0.027)$. Considering both aggregate size and granule stability as correlating dependent variables, the greatest $R^{2}$ value was found when (i) unicellular photoautotroph count $(P=0.036)$, (ii) filamentous photoautotroph count $(P=0.007)$ and (iii) carbohydrate-chlorophyll ratio $(P=0.028)$ remained in the model (the rest being removed due to high $P$ and/or $F$ values). These three parameters could explain $83.0 \%$ of the variation in aggregate size and stability.

\section{Discussion}

\subsection{Spatial mapping of biogeochemical parameters}

As visualised in Fig. 2a and confirmed by CCA (Fig. 3), average carbohydrate concentrations were found to generally increase up-glacier and towards the glacier interior, with some "hotspot" variability evident. With thinner deposits and smaller aggregate sizes, net primary production and the concentration of labile carbohydrates have been found to be greater in the upper ablation zone of the Greenland ice sheet (Cook et al., 2010; Stibal et al., 2010; Telling et al., 2012). Furthermore, microbial EPS production has been shown to be advantageous to survival in cold-temperature environments (Vincent, 2007). When subjected to freezing, polysaccharides can hold larger quantities of unfrozen water than smaller carbohydrates (Biswas et al., 1975), and the hexose monosaccharides - glucose, mannose and galactose - have been found to be better at maintaining liquid water (Furuki, 2000). Both cyanobacterial EPS and cryoconite have been found to contain proportionally greater concentrations of certain hexose monosaccharides, particularly glucose and galactose (Pereira et al., 2009; Stibal et al., 2010). With this in mind, it may be that a proliferation of EPS occurs at the onset of freezing, as a cryoprotection mechanism. Recently thawed cryoconite material, near to the snow line, would thus be expected to contain proportionally more carbohydrates.

Carbohydrate concentration data did show localised variability around the general trend, with concentration "hotspots" evident. Indeed, the carbohydrate:chlorophyll ratio highlights excesses of carbohydrates up-glacier (Fig. 2c), likely to be both a cryoprotection mechanism and a result of phototrophic bloom activity. In the late spring or early summer, supraglacial phototrophic blooms, e.g. those of the red snow alga Chlamydomonas nivalis, can be readily witnessed on both snow and superimposed ice surfaces (Newton, 1982; Müller et al., 1998; Stibal et al., 2006). As such, and given its patchy nature, phototrophic bloom activity likely preferentially raises carbohydrate concentrations in "hotspots" associated with earlier blooms. Furthermore, given the "stickiness" of carbohydrates, it is likely a mechanism for particulate nutrient scavenging following the onset of melt, in order to obtain the necessary nutrients for photosynthesis, e.g. iron for the construction of phycobiliprotein molecules. Nutrient scavenging has been postulated as important within glacial biological communities (e.g. Battin et al., 2001; Hodson et al., 2008) and recently, Varin et al. (2010) have suggested that Arctic microbial mat communities may be optimally structured for nutrient scavenging.

In certain locations near to the glacier edge, and thus valley side, slightly higher carbohydrate concentrations are evident. This might indicate allochthonous input of carbohydrates from the valley sides, or greater allochthonous nutrient inputs and thus higher productivity. Finally, it is considered that the input of larger mineral particles from moraine debris goes some way to explaining the reduced carbohydrate concentrations measured in cryoconite near to the glacier terminus. Indeed spatial studies using Fourier-transform infrared (FTIR) spectroscopy (Langford et al., 2011) provide evidence for localised mineral- and clay-rich cryoconite near to the glacier terminus on Aldegondabreen, another Svalbard glacier.

With regard to chlorophyll $a$ concentrations, whilst the data show heterogeneity, there is a broad increase downglacier and towards the valley sides (Fig. 2b), reaching a maximum value of $2.68 \mu \mathrm{g} \mathrm{g}^{-1}$ near to the glacier terminus. In similar polar environments, between ca. 0.5 and ca. $15 \mu \mathrm{g} \mathrm{g}^{-1}$ of chlorophyll $a$ have been reported (Stibal et al., 2008, 2010; Hodson et al., 2013). With a mean average chlorophyll $a$ concentration of $1.38 \mu^{-1} \mathrm{~g}^{-1}$ (Table 1), concentration values for Longyearbreen are comparable with values from similar polar environments.

The down-glacier increase in chlorophyll $a$ can be attributed, in part, to a reduction in physical disturbance, a trend also seen in glacial streams (Battin et al., 2001). Towards the top of the ablation zone, at the time of sampling, a thick layer of refrozen snowmelt (superimposed ice) was present, which had been weathered by solar radiation to form a "weathering crust" (Müller and Keeler, 1969). This ablating weathering crust, with its distributed pore water flow, likely created increased hydraulic disturbance of the cryoconite sediment contained within it, reducing the opportunity to photosynthesise and perhaps even eroding smaller and weaker cryoconite aggregates. Towards the glacier terminus, preferential supraglacial flow paths and the ablation of the weathering crust, consummate with the exposure and creation of defined cryoconite holes, created regions of the glacier with concentrated water flow (Irvine-Fynn et al., 2012b) versus areas with dispersed surface flow and thus greater stability, promoting photosynthesis. Indeed, the superimposed ice layer could be considered an ephemeral habitat, within which the cyanobacterial strategy of slow growth is likely to be less successful (Vincent, 2007). The main supraglacial stream in 2010 ran down the centre of Longyearbreen glacier, incising deeper in the lower $200 \mathrm{~m}$, potentially to ca. $3 \mathrm{~m}$ below the ice surface (Gulley et al., 2009). This region is concomitant with reduced chlorophyll $a$ content in Fig. 3, a fact that further supports the claim that stability promotes photosynthesis. 
Additionally, the porous and ablating weathering crust upglacier provides shading of the newly ablated cryoconite material within and below it. As such, the level of photosynthetic activity at the time of sampling could well have been lower than for fully exposed, down-glacier cryoconite. Furthermore, exposure time since snowmelt likely plays a part. The up-glacier superimposed ice environment, being only partially ablated, contained biomass only recently exposed to liquid water. Given the low rates of cryoconite mobility reported by Irvine-Fynn et al. (2011), averaging only $5.3 \mathrm{~mm} \mathrm{~d}^{-1}$, and the multi-season preservation of granules (Takeuchi et al., 2010), it is considered likely that cryoconite near to the glacier terminus will have been both older and exposed to IR for the greatest amount of time. This, combined with the fact that chlorophyll produced at low light levels and cold temperatures can degrade more slowly and persist (Carpenter et al., 1986; Vincent and Howard-Williams, 1989), can provide further explanation for the greater chlorophyll concentrations detected near to the glacier terminus. Finally, CCA revealed that proximity to the glacier edge was also driving increased chlorophyll $a$ concentrations (Fig. 3). This likely indicates that short-distance transport of photoautotrophic microorganisms from the surrounding valley sides contributes to the hotspots of chlorophyll $a$ found proximate to the glacier edge.

Concerning phycobiliproteins, mapping did not reveal a discernable spatial trend, indicating a relatively homogeneous cyanobacterial biomass distribution across Longyearbreen, in agreement with the findings of Segawa and Takeuchi (2010). This homogeneous distribution was, however, punctuated by a number of "hotspots" of phycobiliprotein abundance towards the glacier edges and terminus. These "hotspots" suggest heterogeneous cyanobacterial and nutrient influxes from the valley sides, as well as random variation associated with a tendency for cyanobacteria to cluster (Stibal et al., 2010). Research into the variability of phycobiliproteins has found that a range of photo-physical and physico-chemical factors can affect the quantity and quality of phycobiliproteins, including intensity and energy distribution of incident radiation (Glazer, 1977; Korbee et al., 2005), position within the photic zone - the portion of a water/ice body receiving sufficient sunlight for photosynthesis (Jørgensen et al., 1987; Irvine-Fynn and Edwards, 2014), number of motile cyanobacteria (Kruschel and Castenholz, 1998) and macronutrient concentrations (Liotenberg et al., 1996). All of these factors could be expected to contribute to spatial variability in phycobiliprotein concentrations. With different cyanobacteria being different sizes, and thus containing different quantities of phycobiliproteins, it may also be that a degree of functional redundancy exists, whereby several species of cyanobacteria are performing the same ecosystem service and thus can be present in variable numbers. Phycobiliproteins have received little research attention, largely due to extraction difficulties. With those difficulties now being overcome (Lawrenz et al., 2011), and with metagenomic data becoming available (Edwards et al., 2013), there is a real need for further, specific, functional studies of cyanobacteria and their light-harvesting in natural aggregate systems.

Spatial analyses of aggregate size revealed a high variability, with aggregate size, in general, increasing towards the glacier edges. Furthermore, CCA (Fig. 3) exposed a link between the aspect and slope of the glacier surface proximal to the glacier edges and increased aggregate size. This potentially indicates a significant source of avalanched and/or water-borne debris from the valley sides. In addition, this is also an indicator of stability, promoting organic matter production, cell-mineral interaction and amalgamation (Takeuchi et al., 2010; Telling et al., 2012). The central corridor of the ablation zone can be characterised by relatively smaller aggregate sizes, indicative of both reduced debris input from the valley sides and hydraulic erosion proximate to the centrally located supraglacial stream.

Mapping of IR inputs across the ablation surface of Longyearbreen glacier revealed some variability, with inputs being highest towards the snow line and decreasing towards the glacier terminus and particularly the northeast corner of the mapped area. As mentioned, an inverse relationship between cumulative IR and chlorophyll $a$ concentration could be seen, with factors such as shading, period of exposure and erosion likely affecting chlorophyll $a$ concentration. In addition, these comparisons between IR and chlorophyll $a$ concentration suggest that low-light adaptation of photoautotrophic microorganisms, shown as important in shallow, turbid lacustrine ecosystems (Scheffer et al., 1997; Havens et al., 1998), may be a further factor controlling photosynthesis and thus bioaggregation. Furthermore, given that carbohydrate concentrations were found to increase up-glacier, it could be that radiation stresses necessitate microbial carbohydrate production (Chen et al., 2009) to provide a matrix for UV-protective mycosporine-like amino acids (Quesada and Vincent, 1997), in addition to the potential for cryoprotection and nutrient scavenging roles. Finally, cumulative IR receipt was noticeably similar across the upper two thirds of the ablation zone. With this in mind, it is considered that physical factors associated with the glacier's surface, such as shading and erosion within the weathering crust, are likely to be more important in controlling rates of photosynthesis.

\subsection{Comparison of spatial data}

Spatial mapping (Fig. 2) indicates certain visual similarities between elevated pigment (chlorophyll $a$ and phycobiliprotein) concentrations and larger mean aggregate sizes towards the glacier terminus, versus elevated carbohydrate concentrations and smaller aggregate sizes towards the snow line. A positive correlation between chlorophyll $a$ concentration and aggregate size has been found many times when studying microaggregates in a variety of systems (e.g. Maxwell and Neuman, 1994; Lunau et al., 2006; Belnap et al., 2008; 
Bowker et al., 2008). In addition, a positive correlation between chlorophyll $a$ content and soil aggregate stability has been shown in biological soil crust systems (Belnap et al., 2008). Indeed, aggregate stability has been shown to positively correlate with both chlorophyll $a$ content and observations of cyanobacterial sheaths in these soil crust environments (Herrick et al., 2010).

In some contrast to the spatial similarities between chlorophyll $a$ concentrations and aggregate size, carbohydrate concentrations do not show such a strong positive influence upon aggregate size. Although this is contrary to findings with regard to temperate soil microaggregates (e.g. Puget et al., 1999), this finding is not unexpected. Firstly, net ecosystem productivity reduces with sediment thickness (Telling et al., 2012) and, as aggregate size increases, heterotrophic consumption exceeds autotrophic accretion of free carbohydrates (Stibal et al., 2010). Secondly, the carbohydrate extraction method utilised was a gentle, dilute-acid hydrolysis, designed to extract labile carbohydrates from the sediment. The majority of cyanobacteria have capsular, bound carbohydrates surrounding them as a sheath. As such, these findings suggest that bound carbohydrates, as inferred by sediment chlorophyll and phycobiliproteins (Fig. $2 \mathrm{~b}$ and d), exert a greater control over aggregate size than free carbohydrates, in agreement with others (Cook et al., 2010; Stibal et al., 2010).

Spatial statistics (Fig. 3), incorporating a range of photophysical variables extracted from the DEM, support these visual observations, whilst also suggesting: (a) an "edge effect", whereby cryoconite granules proximate to the edges of the glacier were larger, and (b) that photophysical factors contribute greatly to variability across the ablation zone, with aspect being particularly important for aggregate size.

Regarding the "edge effect" uncovered by spatial statistics, Stibal et al. $(2011,2012)$ consider proximity to ice sheet terminus a proxy for the amount of wind-blown input; indeed their data indicate that aeolian input is more important than other inputs (avalanching and runoff) on the scale of the Greenland ice sheet. On the scale of a far smaller valley glacier, it is considered that the "edge effect" likely indicates short-distance transport of both microbial propagules and inorganic particulates from the nearby, deglaciated terrain onto the glacier edges via a variety of mechanisms, with solely aeolian inputs dominating the glacier interior.

Considering the collinearity between aspect and aggregate size, we suggest that, given both the limited mobility of cryoconite upon Arctic glaciers (Irvine-Fynn et al., 2011) and the multi-annual signature seen in cryoconite (Takeuchi et al., 2010), aspect is a proxy for historical IR receipt and age. In addition, aspect has a direct link with proximity to the glacier edge, given the convex nature of Arctic valley glaciers, and also likely has a discrete effect on microclimate. As such, agglomeration of readily available particulate matter proximate to the glacier edge allows increasing aggregate size fuelled by photoautotrophy and inorganic interactions, counter-balanced by the interior decay of carbohydrates, in an environment which is photo-physically stable, with lower IR receipt reducing UV stress (and associated EPS production) and increasing photosynthetic efficiency.

\subsection{Environmental influences over aggregate size and stability}

Biogeochemical data for the centre-line transect indicated that whilst the organic matter content of Longyearbreen cryoconite is greatest towards the terminus, and decreases upglacier, the labile carbohydrate content is greatest near to the snow line and decreases down-glacier. When considered together, these data are in contrast with the findings of Stibal et al. $(2010,2012)$ in Greenland, who found that both total organic carbon and carbohydrate contents increased upglacier; however, the scales at which these data sets were taken are vastly different and the Greenland ice sheet has a defined flatter zone at higher elevations that contains significant cryoconite debris and enhanced productivity. Furthermore, relating this negative correlation between carbohydrate content and organic matter content to aggregate size, it may be suggested that autotrophic production of carbohydrates and the adhesion of allochthonous material up-glacier give way to clay-organic matter interaction and the amalgamation of individual grains down-glacier as controls upon aggregate size (Takeuchi et al., 2010, Telling et al., 2012). As such, these organic matter data may represent younger granules rich in labile, autochthonous carbohydrates ageing within a dynamic weathering crust environment and becoming enriched in both: (i) allochthonous organic matter from the valley sidewalls and (ii) more humified forms of carbon.

Considering the down-transect variation in pigment concentrations, a significant trend in chlorophyll $a$ concentrations was not observed, though spatial data and statistics indicate a broad decrease up-glacier and towards the glacier interior. This up-glacier decrease is likely due to a combination of factors, including stability and persistence. Phycobiliproteins again showed relatively constant average values, with relatively large error bars, meaning that a significant trend could not be determined. Direct counting of filamentous and unicellular photoautotrophs provided further data to compare with aggregate size and stability data, in order to understand the biological controls over aggregation. As mentioned in Sect. 3, the photoautotrophic content of Longyearbreen cryoconite varied considerably along the transect of study. This may be explained by the fact that the quantity and quality of phycobiliproteins have been shown to be highly variable (e.g. Korbee et al., 2005), and the fact that cyanobacterial sheaths may be preserved in the centre of aggregates, away from solar radiation.

Along the glacier centre-line transect, filamentous photoautotroph counts, and the measured length of filaments, showed increases at the glacier terminus and the snow line, whilst unicellular photoautotroph counts showed an inverse 
trend. This may suggest that proliferation of filaments restricts space within the aggregates, reducing growth in unicellular photoautotrophs. It may well also be that cryoconite age and stability, associated with the physics of the weathering crust environment (Irvine-Fynn et al., 2012b), contribute to the greater filament count and length found closest to the glacier terminus. When the photoautotroph data are compared with aggregate size and stability data, it is clear that they show similar trends. This suggests that the presence of filamentous cyanobacteria has a significant control over the size and stability of cryoconite granules, a suggestion that warranted statistical investigation.

Statistical analyses showed that the number of photoautotrophic filaments, and their length, could explain $92.0 \%$ of the variation in cryoconite aggregate size along the transect. Furthermore, when the number of unicellular photoautotrophs and the carbohydrate-chlorophyll ratio were also considered, $83.0 \%$ of the variation in aggregate size and stability could be accounted for. These results suggest that photoautotrophic activity, along with the production of carbohydrates (EPS), contributes significantly to the variation in aggregate size and stability seen on Longyearbreen glacier. These results agree with findings from terrestrial environments, where algal inoculation has been shown to improve soil stability by reducing the damaging effect of erosion by water (Falchini et al., 1996) and retaining silt and clay size fractions (Starks et al., 1981). There is also agreement with findings from marine environments, where substantial research into the stabilisation of sediments by photoautotrophs has been conducted (e.g. Yallop et al., 1994; Sutherland et al., 1998a, b, Noffke et al., 2001, 2003; Tolhurst et al., 2002).

As covered in detail by Stibal et al. (2012), the interplay of various physical and chemical factors, from altitude and slope to nitrogen and phosphorus limitation, all contribute to the variability in microbial productivity, when considering microbial abundance and activity as dependent variables. This study instead uses aggregate size and stability together as dependent variables, in an attempt to improve our current understanding of cryoconite aggregate formation, finding good correlation between cyanobacterial proliferation, associated EPS production, and aggregate size and stability, as suggested previously by a number of authors (e.g. Takeuchi et al., 2001; Hodson et al., 2010; Langford et al., 2010). In addition, this study highlights the importance of the glacier physical and weathering crust environment, particularly aspect, to the size and stability of cryoconite aggregates. As such, it is clear that biological activity, and its associated interplay with chemical and physical parameters, is crucial to cryoconite aggregation. These findings have important implications for the distribution of aeolian debris and microorganisms and their residence time upon the ice, both of which exert a crucial control over albedo (Bøggild et al., 2010; Yallop et al., 2012). Thus, photoautotrophy and the interaction of microorganisms with atmospheric impurities clearly make a significant contribution towards supraglacial melt, forming stable aggregates within which niche communities and microenvironments can develop (Edwards et al., 2013; Zarsky et al., 2013), certainly feeding into, and contributing to the ecology of, both proglacial and fjord environments.

\section{Conclusions}

The spatial variability in both pigment and carbohydrate concentrations across a glacier ablation zone can be rapidly ascertained and quantitatively mapped using a combination of spectrophotometric microplate methods and GIS techniques. This spatial mapping approach determined that free carbohydrates increased up-glacier and towards the interior, likely where newer, thinner deposits and EPS production for cryoprotection and nutrient scavenging are prevalent. Photoautotrophs were ubiquitously present across the glacier surface, with pigment concentrations highest near the glacier terminus and towards the glacier edges, suggesting both allochthonous input and the persistence and proliferation of photoautotrophs in older cryoconite proximate to the relatively stable glacier edge. Aggregate size showed greatest variability, with a general increase towards the edges of the glacier. In all cases, a zone of hydraulic erosion was evident down some of the central tract of the ablation zone, whilst allochthonous input and/or stability contribute to higher values of biogeochemical parameters near the glacier edges. Spatial mapping and statistics (CCA) indicated the importance of photophysical factors for biogeochemical variability across the ablation zone and contrasted the smaller, carbohydraterich granules found in the higher-IR, up-glacier region from the larger, pigment-rich granules found down-glacier and towards its edges.

Centre-line transect data further explored these spatial differences, finding that aggregate size and stability were well correlated along the glacier centre-line, with organic matter and carbohydrate concentrations showing negative correlation, indicative of a shift in organic matter composition and perhaps evidence of increasing age (i.e. humification) down-glacier. The numbers and lengths of filamentous photoautotrophs correlate well with, and can statistically explain, variability in cryoconite aggregate size. Combined with the carbohydrate-chlorophyll ratio, variability in both the aggregate size and stability of cryoconite is explainable. Thus, these data emphasise the strong link between filamentous cyanobacterial proliferation (and associated EPS production) and the development of stable cryoconite macroaggregates, and highlight the importance of both hydraulic erosion and humification to the variability in aggregate size and stability. Additionally, transect data highlight the fact that the spatial mapping of additional biochemical data could improve the utility of these two-dimensional data sets, enabling the further investigation of supraglacial biogeochemistry.

Combined with the spatial data, these results, as a whole, indicate that a combination of photophysical and 
biochemical parameters control the spatial variation in aggregate size and stability. Furthermore, they outline useful procedures for the rapid determination of biochemical parameters on glacier surfaces. The application and development of these methods has the potential to provide two-dimensional temporal mapping of supraglacial biochemistry and to further our understanding of cryoconite granule development. When combined with other data, this could enable the albedo evolution of the glacier surface, the cryoconite mass balance and the associated nutrient balance to be monitored during a photic period or ablation season.

Acknowledgements. H. Langford acknowledges his EPSRC Doctoral Prize Fellowship and R. Smith for assistance with sample collection. A. J. Hodson and TIF acknowledge the RGS (Fleming award), NGS and Gilchrist Education Trust awards. TIF also recognises support from the Climate Change Consortium of Wales.

Edited by: S. Pantoja

\section{References}

Anesio, A. M., Sattler, B., Foreman, C., Telling, J., Hodson, A., Tranter, M., and Psenner, R.: Carbon fluxes through bacterial communities on glacier surfaces, Ann. Glaciol., 51, 32-40, 2010.

Bar-Or, Y. and Shilo, M.: The role of cell-bound flocculants in coflocculation of benthic cyanobacteria with clay particles, FEMS Microbiol. Ecol., 53, 169-174, 1988.

Battin, T. J., Wille, A., Sattler, B., and Psenner, R.: Phylogenetic and functional heterogeneity of sediment biofilms along environmental gradients in a glacial stream, Appl. Environ. Microb., 67, 799-807, 2001.

Beer, S. and Eshel, A.: Determining phycoerythrin and phycocyanin concentrations in aqueous crude extracts of red algae, Aust. J. Mar. Fresh. Res., 36, 785-792, 1985.

Belnap, J., Phillips, S. L., Witwicki, D. L., and Miller, M. E.: Visually assessing the level of development and soil surface stability of cyanobacterially dominated biological soil crusts, J. Arid Environ., 72, 1257-1264, 2008.

Biswas, A. B., Kumsah, C. A., Pass, G., and Phillips, G. O.: Effect of carbohydrates on heat of fusion of water, J. Solution Chem., 4, 581-590, 1975.

Bøggild, C. E., Brandt, R. E., Brown, K. J., and Warren, S. G.: The ablation zone in northeast Greenland: ice types, albedos and impurities, J. Glaciol., 56, 101-113, 2010.

Bowker, M. A., Belnap, J., Chaudhary, V. B., and Johnson, N. C.: Revisiting classic water erosion models in drylands: the strong impact of biological soil crusts, Soil Biol. Biochem., 40, 23092316, 2008.

Bruland, O., Maréchal, D., Sand, K., and Killingtveit, Å.: Energy and water balance studies of a snow cover during snowmelt period at a high arctic site, Theor. Appl. Climatol., 70, 53-63, 2001.

Cameron, K. A., Hodson, A. J., and Osborn, A. M.: Structure and diversity of bacterial, eukaryotic and archaeal communities in glacial cryoconite holes from the Arctic and the Antarctic, FEMS Microbiol. Ecol., 82, 254-267, 2012.
Carpenter, S. R., Elser, M. M., and Elser, J. J.: Chlorophyll production, degradation, and sedimentation - implications for paleolimnology, Limnol. Oceanogr., 31, 112-124, 1986.

Chen, L. Z., Wang, G. H., Hong, S., Liu, A., Li, C., and Liu, Y. D.: UV-B-induced oxidative damage and protective role of exopolysaccharides in desert cyanobacterium Microcoleus vaginatus, J. Integr. Plant Biol., 51, 194-200, 2009.

Cheshire, M. V., Mundie, C. M., and Shepherd, H.: Transformation of carbohydrate constituents of grass during decomposition in soil, J. Sci. Food Agr., 30, 330-330, 1979.

Clark, D.: Understanding Canonical Correlation Analysis, Concepts and Techniques in Modern Geography, No. 3, Geo Abstracts Ltd, Norwich, 1975.

Cook, J., Hodson, A., Telling, J., Anesio, A., Irvine-Fynn, T., and Bellas, C.: The mass-area relationship within cryoconite holes and its implications for primary production, Ann. Glaciol., 51, 106-110, 2010.

De Phillipis, R. and Vincenzini, M.: Exocellular polysaccharides from cyanobacteria and their possible applications, FEMS Microbiol. Rev., 22, 151-175, 1998.

Decho, A. W.: Microbial exopolymer secretions in ocean environments: their role(s) in food webs and marine processes, Oceanogr. Mar. Biol., 28, 73-154, 1990.

Decho, A. W. and Lopez, G. R.: Exopolymer microenvironments of microbial flora - multiple and interactive effects on trophic relationships, Limnol. Oceanogr., 38, 1633-1645, 1993.

Downing, J. A. and Rath, L. C.: Spatial patchiness in the lacustrine sedimentary environment, Limnol. Oceanogr., 33, 447-458, 1988.

Dubois, M., Gilles, K., Hamilton, J. K., Rebers, P. A., and Smith, F.: A colorimetric method for the determination of sugars, Nature, 168, 167-167, 1951.

Edwards, A., Anesio, A. M., Rassner, S. M., Sattler, B., Hubbard, B., Perkins, W. T., Young, M., and Griffith, G. W.: Possible interactions between bacterial diversity, microbial activity and supraglacial hydrology of cryoconite holes in Svalbard, ISME J., 5, 150-160, 2010.

Edwards, A., Rassner, S. M., Anesio, A. M., Worgan, H. J., IrvineFynn, T. D., Williams, H. W., Sattler, B., and Griffith, G. W. Contrasts between the cryoconite and ice-marginal bacterial communities of Svalbard glaciers, Polar Res., 32, 2013.

Etzelmüller, B., Ødegård, R. S., Vatne, G., Mysterud, R. S., Tonning, T., and Sollid, J. L.: Glacier characteristics and sediment transfer system of Longyearbreen and Larsbreen, western Spitsbergen, Norwegian J. Geogr., 54, 157-168, 2000.

Falchini, L., Sparvoli, E., and Tomaselli, L.: Effect of Nostoc (cyanobacteria) inoculation on the structure and stability of clay soils, Biol. Fert. Soils, 23, 346-352, 1996.

Fischer, H., Meyer, A., Fischer, K., and Kuzyakov, Y.: Carbohydrate and amino acid composition of dissolved organic matter leached from soil, Soil Biol. Biochem., 39, 2926-2935, 2007.

Foreman, C. M., Sattler, B., Mikucki, J. A., Porazinska, D. L., and Priscu, J. C.: Metabolic activity and diversity of cryoconites in the Taylor Valley, Antarctica, J. Geophys. Res.-Biogeo., 112, G04S32, doi:10.1029/2006JG000358, 2007.

Foreman, C. M., Sattler, B., Mikucki, J. A., Porazinska, D. L., and Priscu, J. C.: Metabolic activity and diversity of cryoconites in the Taylor Valley, Antarctica, J. Geophys. Res.-Biogeo., 112, G04S32, doi:10.1029/2006JG000358, 2007. 
Furuki, T.: Effect of stereochemistry on the anti-freeze characteristics of carbohydrates, a thermal study of aqueous monosaccharides at subzero temperatures, Carbohyd. Res., 323, 185-191, 2000.

Glazer, A. N.: Structure and molecular organization of photosynthetic accessory pigments of cyanobacteria and red algae, Mol. Cell. Biochem., 18, 125-140, 1977.

Grossman, A. R., Schaefer, M. R., Chiang, G. G., and Collier, J. L.: The phycobilisome, a light-harvesting complex responsive to environmental conditions, Microbiol. Rev., 57, 725-749, 1993.

Gulley, J. D., Benn, D. I., Muller, D., and Luckman, A.: A cut-andclosure origin for englacial conduits in uncrevassed regions of polythermal glaciers, J. Glaciol., 55, 66-80, 2009.

Hanssen-Bauer, I., Solås, M. K., and Steffensen, E. L.: Climate of Spitsbergen, DNMI, 1990.

Hardy, R. L.: Multiquadric equations of topography and other irregular surfaces, J. Geophys. Res., 76, 1905-1915, 1971.

Havens, K. E., Phlips, E. J., Cichra, M. F., and Li, B.-L.: Light availability as a possible regulator of cyanobacteria species composition in a shallow subtropical lake, Freshwater Biol., 39, 547-556, 1998.

Herrick, J. E., Van Zee, J. W., Belnap, J., Johansen, J. R., and Remmenga, M.: Fine gravel controls hydrologic and erodibility responses to trampling disturbance for coarse-textured soils with weak cyanobacterial crusts, Catena, 83, 119-126, 2010.

Hodson, A., Anesio, A. M., Tranter, M., Fountain, A., Osborn, M., Priscu, J., Laybourn-Parry, J., and Sattler, B.: Glacial ecosystems, Ecol. Monogr., 78, 41-67, 2008.

Hodson, A., Cameron, K., Boggild, C., Irvine-Fynn, T., Langford, H., Pearce, D., and Ban- wart, S.: The structure, biological activity and biogeochemistry of cryoconite aggregates upon an Arctic valley glacier: Longyearbreen, Svalbard, J. Glaciol., 56, 349362, 2010.

Hodson, A., Paterson, H., Westwood, K., Cameron, K., and Laybourn-Parry, J.: A blue-ice ecosystem on the margins of the East Antarctic ice sheet, J. Glaciol., 59, 255, 2013. 29

Holm-Hansen, O. and Riemann, B.: Chlorophyll $a$ determination improvements in methodology, Oikos, 30, 438-447, 1978.

Irvine-Fynn, T. D. and Edwards, A.: A frozen asset: The potential of flow cytometry in constraining the glacial biome, Cytometry Part A, 85, 3-7, 2014.

Irvine-Fynn, T. D. L., Bridge, J. W., and Hodson, A. J.: Rapid quantification of cryoconite: granule geometry and in situ supraglacial extents, using examples from Svalbard and Greenland, J. Glaciol., 56, 297-308, 2010.

Irvine-Fynn, T. D., Bridge, J. W., and Hodson, A. J.: In situ quantification of supraglacial cryoconite morphodynamics using timelapse imaging: an example from Svalbard, J. Glaciol., 57, 651657, 2011.

Irvine-Fynn, T. D. L., Hanna, E., Barrand, N. E., Porter, P. R., Kohler, J., and Hodson, A. J.: Examination of a physically based, high-resolution, distributed Arctic temperature-index melt model, on Midtre Lovénbreen, Svalbard, Hydrol. Process., 28, 134-149, 2012a.

Irvine-Fynn, T. D. L., Edwards, A., Newton, S., Langford, H., Rassner, S. M., Telling, J., Anesio, A. M., and Hodson, A. J.: Microbial cell budgets of an Arctic glacier surface quantified using flow cytometry, Environ. Microbiol. 14, 2998-3012, 2012 b.
Jørgensen, B. B., Cohen, Y., and Desmarais, D. J.: Photosynthetic action spectra and adaptation to spectral light distribution in a benthic cyanobacterial mat, Appl. Environ. Microb., 53, 879886, 1987.

Korbee, N., Figueroa, F. L., and Aguilera, J.: Effect of light quality on the accumulation of photosynthetic pigments, proteins and mycosporine-like amino acids in the red alga Porphyra leucosticta (Bangiales, Rhodophyta), J. Photoch. Photobio. B, 80, 7178, 2005.

Kreith, F. and Kreider, J. F.: Principles of Solar Engineering, Hemisphere, Washington DC, 1978.

Kruschel, C. and Castenholz, R. W.: The effect of solar UV and visible irradiance on the vertical movements of cyanobacteria in microbial mats of hypersaline waters, FEMS Microbiol. Ecol., 27, 53-72, 1998.

Langford, H., Hodson, A., and Banwart, S.: Using FTIR spectroscopy to characterise the soil mineralogy and geochemistry of cryoconite from Aldegondabreen glacier, Svalbard, Appl. Geochem., 26, S206-S209, 2011.

Langford, H., Hodson, A., Banwart, S., and Boggild, C.: The microstructure and biogeochemistry of Arctic cryoconite granules, Ann. Glaciol., 51, 87-94, 2010.

Lawrenz, E., Fedewa, E., and Richardson, T.: Extraction protocols for the quantification of phycobilins in aqueous phytoplankton extracts, J. Appl. Phycol., 23, 865-871, 2011.

Lee, T., Tsuzuki, M., Takeuchi, T., Yokoyama, K., and Karube, I.: In vivo fluorometric method for early detection of cyanobacterial waterblooms, J. Appl. Phycol., 6, 489-495, 1994.

Liotenberg, S., Campbell, D., Rippka, R., Houmard, J., and Tandeau de Marsac, N.: Effect of the nitrogen source on phycobiliprotein synthesis and cell reserves in a chromatically adapting filamentous cyanobacterium, Microbiology UK, 142, 611-622, 1996.

Lunau, M., Lemke, A., Dellwig, O., and Simon, M.: Physical and biogeochemical controls of microaggregate dynamics in a tidally affected coastal ecosystem, Limnol. Oceanogr., 51, 847-859, 2006.

Masuko, T., Minami, A., Iwasaki, N., Majima, T., Nishimura, S. I., and Lee, Y. C.: Carbohydrate analysis by a phenol-sulfuric acid method in microplate format, Anal. Biochem., 339, 69-72, 2005.

Maxwell, C. D. and Neuman, C. M.: Photoautotrophs and the microaggregation of sand in a fresh-water beach dune complex implications for sediment transport by wind, Soil Biol. Biochem., 26, 221-233, 1994.

Mcintyre, N. F.: Cryoconite hole thermodynamics, Can. J. Earth Sci., 21, 152-156, 1984.

Morato, J. P., Roget, E., and Lozovatsky, I.: Statistics of microstructure patchiness in a stratified lake, J. Geophys. Res.-Oceans, 116, C10035, doi:10.1029/2010JC006911, 2011.

Müller, F. and Keeler, C. M.: Errors in short-term ablation measurements on melting ice surfaces, J. Glaciol., 8, 91-105, 1969.

Müller, T., Bleiss, W., Martin, C. D., Rogaschewski, S., and Fuhr, G.: Snow algae from northwest Svalbard: their identification, distribution, pigment and nutrient content, Polar Biol., 20, 14-32, 1998.

Murata, N. and Sato, N.: Studies on the absorption spectra of chlorophyll $a$ in aqueous dispersions of lipids from the photosynthetic membranes, Plant Cell Physiol., 19, 401-410, 1978.

Myklestad, S. and Haug, A.: Production of carbohydrates by the marine diatom Chaetoceros affinis var willei (Gran) Hustedt, I. 
Effect of the concentration of nutrients in the culture medium, $\mathrm{J}$. Exp. Mar. Biol. Ecol., 9, 125-136, 1972.

Newton, A. P. W.: Red-colored snow algae in Svalbard - some environmental factors deter- mining the distribution of Chlamydomonas nivalis (Chlorophyta volvocales), Polar Biol., 1, 167172, 1982.

Noffke, N., Gerdes, G., and Klenke, T.: Benthic cyanobacteria and their influence on the sedimentary dynamics of peritidal depositional systems (siliciclastic, evaporitic salty, and evap- oritic carbonatic), Earth-Sci. Rev., 62, 163-176, 2003.

Noffke, N., Gerdes, G., Klenke, T., and Krumbein, W. E.: Microbially induced sedimentary structures - a new category within the classification of primary sedimentary structures, J. Sediment. Res., 71, 649-656, 2001.

Nuth, C., Moholdt, G., Kohler, J., Hagen, J. O., and Kääb, A.: Svalbard glacier elevation changes and contribution to sea level rise, J. Geophys. Res.-Earth, 115, F01008, doi:10.1029/2008JF001223, 2010.

Oades, J. M.: Soil organic matter and structural stability - mechanisms and implications for management, Plant Soil, 76, 319-337, 1984.

Ortega-Calvo, J. J. and Stal, L. J.: Sulfate-limited growth in the N-2fixing unicellular cyanobac- terium Gloeothece (Nageli) sp PCC6909, New Phytol., 128, 273-281, 1994.

Pearce, D. A., Bridge, P. D., Hughes, K. A., Sattler, B., Psenner, R., and Russell, N. J.: Microorganisms in the atmosphere over Antarctica, FEMS Microbiol. Ecol., 69, 143-157, 2009.

Pereira, S., Zille, A., Micheletti, E., Moradas-Ferreira, P., De Philippis, R., and Tamagnini, P.: Complexity of cyanobacterial exopolysaccharides: composition, structures, inducing factors and putative genes involved in their biosynthesis and assembly, FEMS Microbiol. Rev., 33, 917-941, 2009.

Porra, R. J., Thompson, W. A., and Kriedemann, P. E.: Determination of accurate extinction coefficients and simultaneous equations for assaying chlorophylls $a$ and $b$ extracted with four different solvents: verification of the concentration of chlorophyll standards by atomic absorption spectroscopy. Biochim. Biophys. Acta, 975, 384-394, 1989.

Puget, P., Angers, D. A., and Chenu, C.: Nature of carbohydrates associated with water-stable aggregates of two cultivated soils, Soil Biol. Biochem., 31, 55-63, 1999.

Quesada, A. and Vincent, W. F.: Strategies of adaptation by Antarctic cyanobacteria to ultraviolet radiation, Eur. J. Phycol., 32, 335342, 1997.

Sartory, D. P. and Grobbelaar, J. U.: Extraction of chlorophyll $a$ from fresh-water phytoplankton for spectrophotometric analysis, Hydrobiologia, 114, 177-187, 1984.

Sattler, B., Storrie-Lombardi, M. C., Foreman, C. M., Tilg, M., and Psenner, R.: Laser-induced fluorescence emission (LIFE) from Lake Fryxell (Antarctica) cryoconites, Ann. Glaciol., 51, 145$152,2010$.

Säwström, C., Mumford, P., Marshall, W., Hodson, A., and Laybourn-Parry, J.: The microbial communities and primary productivity of cryoconite holes in an Arctic glacier (Svalbard 79 N), Polar Biol., 25, 591-596, 2002.

Scheffer, M., Rinaldi, S., Gragnani, A., Mur, L. R., and Van Nes, E. H.: On the dominance of filamentous cyanobacteria in shallow, turbid lakes, Ecology, 78, 272-282, 1997.
Schnitzer, M.: Organic matter characterisation, in Page, A. L.: Methods of soil analysis, part 2, chemical and microbiological properties, Soil Science Society of America, Madison, WI, 581594, 1982.

Segawa, T. and Takeuchi, N.: Cyanobacterial communities on Qiyi glacier, Qilian Shan, China, Ann. Glaciol., 51, 135-144, 2010.

Starks, T. L., Shubert, L. E., and Trainor, F. R.: Ecology of soil algae: a review, Phycologia, 20, 65-80, 1981.

Stewart, D. E. and Farmer, F. H.: Extraction, identification, and quantitation of phycobiliprotein pigments from phototrophic plankton, Limnol. Oceanogr., 29, 392-397, 1984.

Stibal, M., Lawson, E. C., Lis, G. P., Mak, K. M., Wadham, J. L., and Anesio, A. M.: Organic matter content and quality in supraglacial debris across the ablation zone of the Greenland ice sheet, Ann. Glaciol., 51, 1-8, 2010.

Stibal, M., Sabacka, M., and Kastovska, K.: Microbial communities on glacier surfaces in Svalbard: impact of physical and chemical properties on abundance and structure of cyanobacteria and algae, Microb. Ecol., 52, 644-654, 2006.

Stibal, M., Telling, J., Cook, J., Mak, K. M., Hodson, A., and Anesio, A. M.: Environmental controls on microbial abundance and activity on the Greenland ice sheet: a multivariate analysis approach, Microb. Ecol., 63, 74-84, 2012.

Stibal, M., Tranter, M., Benning, L. G., and Rehak, J.: Microbial primary production on an Arctic glacier is insignificant in comparison with allochthonous organic carbon input, Environ. Microbiol., 10, 2172-2178, 2008.

Sutherland, T. F., Amos, C. L., and Grant, J.: The effect of buoyant biofilms on the erodibility of sublittoral sediments of a temperate microtidal estuary, Limnol. Oceanogr., 43, 225-235, 1998a.

Sutherland, T. F., Grant, J., and Amos, C. L.: The effect of carbohydrate production by the diatom Nitzschia curvilineata on the erodibility of sediment, Limnol. Oceanogr., 43, 65-72, 1998 b.

Swain, E. B.: Measurement and interpretation of sedimentary pigments, Freshwater Biol., 15, 53-75, 1985.

Takeuchi, N., Kohshima, S., and Seko, K.: Structure, formation, and darkening process of albedo-reducing material (cryoconite) on a Himalayan glacier: a granular algal mat growing on the glacier, Arct. Antarct. Alp. Res., 33, 115-122, 2001.

Takeuchi, N., Nishiyama, H., and Li, Z. Q.: Structure and formation process of cryoconite granules on Urumqi glacier No. 1, Tien Shan, China, Ann. Glaciol., 51, 9-14, 2010.

Tieber, A., Lettner, H., Bossew, P., Hubmer, A., Sattler, B., and Hofmann, W.: Accumulation of anthropogenic radionuclides in cryoconites on Alpine glaciers, J. Environ. Radioactiv., 100, 590598, 2009.

Telling, J., Anesio, A. M., Hawkings, J., Tranter, M., Wadham, J. L., Hodson, A. J., Irvine- Fynn, T., and Yallop, M. L.: Measuring rates of gross photosynthesis and net community production in cryoconite holes: a comparison of field methods, Ann. Glaciol., 51, 153-162, 2010.

Telling, J., Anesio, A. M., Tranter, M., Stibal, M., Hawkings, J., Irvine-Fynn, T., Hodson, A., Butler, C., Yallop, M., and Wadham, $\mathrm{J}$.: Controls on the autochthonous production and respiration of organic matter in cryoconite holes on high Arctic glaciers, J. Geophys. Res., 117, G01017, doi:10.1029/2011JG001828, 2012.

Thompson, R. C., Tobin, M. L., Hawkins, S. J., and Norton, T. A.: Problems in extraction and spectrophotometric determination of 
chlorophyll from epilithic microbial biofilms: towards a standard method, J. Mar. Biol. Assoc. UK, 79, 551-558, 1999.

Tisdall, J. M.: Possible role of soil microorganisms in aggregation in soils, Plant Soil, 159, 115-121, 1994.

Tisdall, J. M. and Oades, J. M.: Organic matter and water-stable aggregates in soils, J. Soil Sci., 33, 141-163, 1982.

Tolhurst, T. J., Gust, G., and Paterson, D. M.: The influence of an extracellular polymeric sub- stance (EPS) on cohesive sediment stability, Proceed. Mar. Sci., 5, 409-425, 2002.

Underwood, G. J. C. and Paterson, D. M.: Seasonal changes in diatom biomass, sediment stability and biogenic stabilization in the Severn Estuary, J. Mar. Biol. Assoc. UK, 73, 871-887, 1993.

Varin, T., Lovejoy, C., Jungblut, A. D., Vincent, W. F., and Corbeil, J.: Metagenomic profiling of Arctic microbial mat communities as nutrient scavenging and recycling systems, Limnol. Oceanogr., 55, 1901-1911, 2010.

Vincent, W. F.: Cold tolerance in cyanobacteria and life in the cryosphere, in: Cellular Origin and Life in Extreme Habitats and Astrobiology, Springer, Berlin, 2007.

Vincent, W. F. and Howard-Williams, C.: Microbial communities in Southern Victoria Land streams (Antarctica), 2. The effects of low temperature, Hydrobiologia, 172, 39-49, 1989.

Warren, C. R.: Rapid measurement of chlorophylls with a microplate reader, J. Plant Nutr., 31, 1321-1332, 2008.

Wildman, R. B. and Bowen, C. C.: Phycobilisomes in blue-green algae, J. Bacteriol., 117, 866-881, 1974.
Xu, Y., Simpson, A. J., Eyles, N., and Simpson, M. J.: Sources and molecular composition of cryoconite organic matter from the Athabasca Glacier, Canadian Rocky Mountains, Org. Geochem., 41, 177-186, 2009.

Yallop, M. L., Anesio, A. M., Perkins, R. G., Cook, J., Telling, J., Fagan, D., MacFarlane, J., Stibal, M., Barker, G., Bellas, C., Hodson, A., Tranter, M., Wadham, J., and Roberts, N. W.: Photophysiology and albedo-changing potential of the ice algal community on the surface of the Greenland ice sheet, ISME J., 6, 2302-2313, 2012.

Yallop, M. L., Dewinder, B., Paterson, D. M., and Stal, L. J.: Comparative structure, primary production and biogenic stabilization of cohesive and non-cohesive marine sediments inhabited by microphytobenthos, Estuar. Coast. Shelf S., 39, 565-582, 1994.

Yde, J. C., Riger-Kusk, M., Christiansen, H. H., Knudsen, N. T. and Humlum, O.: Hydrochemical characteristics of bulk meltwater from an entire ablation season, Longyearbreen, Svalbard, J. Glaciol., 54, 259-272, 2008.

Zarsky, J. D., Stibal, M., Hodson, A., Sattler, B., Schostag, M., Hansen, L. H., Jacobsen, C. S. and Psenner, R.: Large cryoconite aggregates on a Svalbard glacier support a diverse microbial community including ammonia-oxidizing archaea. Env. Res. Let., 8, 035044, doi:10.1088/1748-9326/8/3/035044, 2013.

Zulpa De Caire, G., Storni De Cano, M., Zaccaro De Mule, M. C., Palma, R. M., and Colombo, K.: Exopolysaccharide of Nostoc muscorum (cyanobacteria) in the aggregation of soil particles, J. Appl. Phycol., 9, 249-253, 1997. 